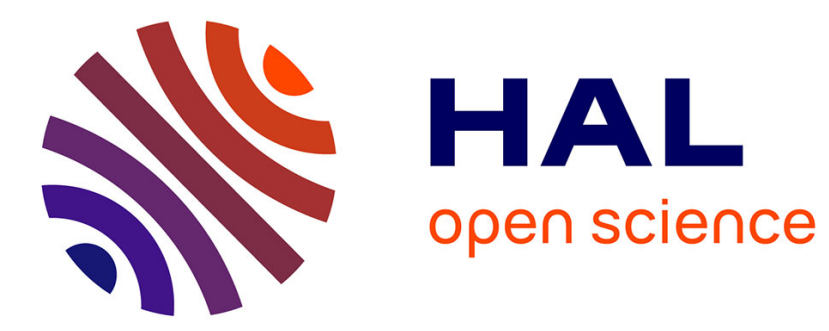

\title{
Serpentinization of New Caledonia peridotites: from depth to (sub-)surface
}

\author{
Marc Ulrich, Manuel Munoz, Philippe Boulvais, Michel Cathelineau, \\ Dominique Cluzel, Stephane Guillot, Christian Picard
}

\section{- To cite this version:}

Marc Ulrich, Manuel Munoz, Philippe Boulvais, Michel Cathelineau, Dominique Cluzel, et al.. Serpentinization of New Caledonia peridotites: from depth to (sub-)surface. Contributions to Mineralogy and Petrology, 2020, 75 (9), pp.91. 10.1007/s00410-020-01713-0 . insu-02890835

\section{HAL Id: insu-02890835 \\ https://hal-insu.archives-ouvertes.fr/insu-02890835}

Submitted on 7 Jul 2020

HAL is a multi-disciplinary open access archive for the deposit and dissemination of scientific research documents, whether they are published or not. The documents may come from teaching and research institutions in France or abroad, or from public or private research centers.
L'archive ouverte pluridisciplinaire HAL, est destinée au dépôt et à la diffusion de documents scientifiques de niveau recherche, publiés ou non, émanant des établissements d'enseignement et de recherche français ou étrangers, des laboratoires publics ou privés. 
Serpentinization of New Caledonia peridotites: from

1

Marc ULRICH ${ }^{1}$, Manuel MUÑOZ ${ }^{2}$, Philippe BOULVAIS ${ }^{3}$, Michel CATHELINEAU ${ }^{4}$, Dominique CLUZEL ${ }^{5}$, Stéphane GUILLOT ${ }^{6}$, Christian PICARD ${ }^{7}$.

${ }^{1}$ Université de Strasbourg, CNRS, IPGS UMR 7516, F-67000 Strasbourg

${ }^{2}$ Géosciences Montpellier, Univ. Montpellier, CNRS, Montpellier, France

${ }^{3}$ Géosciences Rennes-UMR 6118, University Rennes, CNRS, F-35000 Rennes, France

${ }^{4}$ Georessources CNRS UMR 7566, Vandoeuvre-lès-Nancy, France

${ }^{5}$ ISEA, Université de la Nouvelle-Calédonie, BP R4, 98851 Nouméa Cedex, New Caledonia

${ }^{6}$ Univ. Grenoble Alpes, Univ. Savoie Mont Blanc, CNRS, IRD, IFSTTAR, ISTerre, 38000

Grenoble, France

${ }^{7}$ Laboratoire Chrono-environnement CNRS UMR 6249 Besançon, France

Keywords: Serpentinization, New Caledonia ophiolite, subduction, obduction, serpentine geochemistry, meteoric fluid circulation. 
Serpentinization processes occur at geological settings notably during oceanic subduction and obduction, where mantle rocks interact with water. Different types of serpentine minerals form according to temperature and pressure conditions, and potentially chemical exchanges. Therefore, the characterization of serpentine minerals, and the possible occurrence of multiple serpentine generations in mantle rocks provide essential constraints on the conditions of fluid-rock interactions in the mantle. The serpentinite sole of the Peridotite Nappe of New Caledonia (Southwest Pacific) is the result of several superimposed serpentinisation events. The latter were discriminated using mineralogical and geochemical approaches and modeling.

Lizardite represents more than $80 \%$ of the entire serpentine content of the ophiolite. It is crosscut by several veins of other serpentine species in the serpentinite sole. The relative chronology appears as follows: lizardite $1 \rightarrow$ lizardite $2 \rightarrow$ antigorite $\rightarrow$ chrysotile $\rightarrow$ polygonal serpentine. The transition from primary/magmatic minerals to lizardite 1 is almost isochemical. Then, the development of lizardite 2 yields an enrichment in fluid-mobile elements such as $\mathrm{Cs}, \mathrm{Rb}, \mathrm{Ba}, \mathrm{U}$ and light rare-earth elements and an apparent increase of the $\mathrm{Fe}^{3+} / \mathrm{Fe}_{\mathrm{T}}$ ratio. The modeling of $\delta^{18} \mathrm{O}$ values (1.9\% to $13.9 \%$ ) and $\delta \mathrm{D}$ values $(88 \%$ o to $106 \%$ ) of all serpentine species through Monte-Carlo simulations show that New Caledonia serpentines were mainly formed in equilibrium with fluids released by the dehydration of altered oceanic crust (AOC) during subduction between $250^{\circ} \mathrm{C}$ and $350^{\circ} \mathrm{C}$. AOC-derived fluids are not the unique source of fluids since a low temperature $\left(100-150^{\circ} \mathrm{C}\right)$ meteoric component is also predicted by the models. Thus, serpentine acts as a tape-recorder of fluidrock interactions into the mantle from depth to (sub-)surface.

\section{INTRODUCTION}

Serpentinization is a hydrothermal alteration process that leads to upper mantle hydration. Serpentine minerals are ubiquitous in ultramafic rocks from various geological settings and their crucial role in tectonic and chemical processes has been widely documented over the past two decades: In divergent environments, which include ultraslow and slow-spreading centers and mantleexhuming passive margins, serpentine occurs mainly along fractures and detachment faults, weakening the upper mantle, promoting strain localization and resulting in the exhumation of serpentinized peridotites at the seafloor (Andréani et al. 2014; 2007; Cannat et al. 1995; Chenin et al. 2017; Delacour et al. 2008; Gillard et al. 2019; Guillot et al. 2015; Mével 2003; Picazo et al. 2012). Such tectonic processes involve significant mass transfer between the mantle and oceanic reservoirs (Alt and Shanks III 2003; Iyer et al. 2008; Kodolanyi et al. 2012; Pinto et al. 2016; Rouméjon et al. 2015; Schwarzenbach et al. 2015). Also, the rheology of serpentinized rocks strongly influences deformation and seismicity in the forearc and controls geodynamics of the subduction zone 
(Hyndman and Peacock 2003; Peacock and Hyndman 1999; Stern 2002). Here again, serpentine is assumed to be one of the most efficient ways to recycle water and fluid-mobile elements (FME) into the deeper mantle (Debret et al. 2013; Deschamps et al. 2012; 2011; Klein et al. 2017; Poli and Schmidt 2002; Rüpke et al. 2004; Savov et al. 2005; Scambelluri et al. 2004). Thus, the uppermost part of the oceanic lithosphere is hydrothermally altered before entering subduction zones. Then, the dehydration of the subducting slab favors the formation of forearc serpentine, which hosts a large amount of water (up to $\sim 13 \mathrm{wt} . \%$ ). The circulation of such an amount of aqueous fluids may, in turn, transport fluid-mobile elements (FME) deep into the mantle down to $\sim 150 \mathrm{~km}$ (Ulmer and Trommsdorff 1995; Wunder et al. 2001). At temperature above $\sim 650^{\circ} \mathrm{C}$, serpentine is no longer stable and aqueous fluids are liberated by serpentine breakdown, triggering mantle wedge melting that gives rise to arc volcanism (Hattori and Guillot 2003; Iwamori 1998; Reynard 2013; Schmidt and Poli 1998; Ulmer and Trommsdorff 1995; 1999). Therefore, studying serpentinite is fundamental in the aim of addressing questions about plate tectonics and global geochemical cycles.

When convergence results in the closure of ocean basins, slices of the forearc mantle may be obducted. Serpentinite then acts as a lubricant, facilitating the ophiolite emplacement and subsequent exhumation of the high pressure rocks (Agard et al. 2016; Guillot et al. 2009; 2000; Schwartz et al. 2001). However, the conditions of fluid-rock interactions and serpentine formation, as well as the nature and source of serpentinizing fluids, are mostly unconstrained.

In New Caledonia (NC), large ultramafic massifs form an extensive and well-exposed ophiolite obducted during the Late Eocene, termed Peridotite Nappe (Figure 1; Avias 1967). Peridotites recorded various degrees of serpentinization, and the base of the Peridotite Nappe is made of a thick serpentinite sole characterized by multiple generations of serpentine veins, the origin of which remains unclear (Frost et al. 2013; Gautier et al. 2016; Mothersole et al. 2017; Quesnel et al. 2016b; Ulrich et al. 2014). In this paper, the source and nature of the fluids involved in the serpentinization are therefore unraveled thanks to new petrological, mineralogical and geochemical data as well as geochemical modeling.

\section{GEOLOGICAL SETTINGS}

New Caledonia is an island of the SW Pacific, $\sim 1300 \mathrm{~km}$ to the east of Australia, which forms the northernmost part of the Norfolk Ridge, an elongated slice of thinned and largely submarine continental crust, rifted from the Gondwana margin during the Late Cretaceous. The Peridotite Nappe tectonically overlies a patchwork of pre-Oligocene terranes and covers at present about onethird of the island. The main unit is located in the south of the island, so-called Massif du Sud, and several tectonic klippes are spread along the West coast (Figure 1). All these units result from the evolution of a marginal basin that opened to the east of the Norfolk Ridge during the Campanian- 
Paleocene (90 Ma-55 Ma; Cluzel et al. 2001). This basin was inverted at $56 \mathrm{Ma}$ by northeastward-

subduction (Cluzel et al. 2012a) and the upper plate of the system (the Loyalty Basin) was obducted at ca. $34 \mathrm{Ma}$ (Cluzel et al. 1998) when the Norfolk ridge entered the trench and jammed the Eocene subduction. Harzburgites and dunites formed in a supra-subduction zone environment are predominant, while lherzolites, inherited from the initial marginal basin are also found in the northernmost massifs (Pirard et al. 2013; Secchiari et al. 2016; 2019; Ulrich et al. 2010). The Peridotite Nappe bears a lateritic regolith (up to $100 \mathrm{~m}$ thick) that contains $\sim 10 \%$ of the world Ni reserves (McRae 2018). The Peridotite nappe overlies the Poya Terrane, which corresponds to a large composite allochthon formed of two sub-units: i) tectonic slices of massive and pillow basalt (Poya Terrane Basalts) of dominant MORB affinity and abyssal argillites of Campanian to Early Eocene age (Aitchison et al. 1995), derived from the upper oceanic crust of the South Loyalty Basin (Cluzel et al. 1997; Eissen et al. 1998) and accreted in the fore-arc region of the Loyalty Arc (Cluzel et al. 2001), and ii) Coniacian-Santonian distal turbidites (Kone Facies) accumulated on the ancient passive margin of the Norfolk Ridge, and intruded by lower Eocene dolerite sills of EMORB affinity (Cluzel et al. 2018).

The serpentinization processes of the Peridotite Nappe have never been studied in-depth, while peridotites are highly serpentinized. Orloff (1968) highlighted, for the first time, the decreasing degree of serpentinization from bottom to the top of the ophiolite. More recently, Frost et al. (2013) identified three generations of serpentine veins in a dunite sample: two-first generations of lizardite and the last one of chrysotile. The transformation of lizardite to chrysotile would have been accompanied by the release of $\mathrm{Fe}$ and the subsequent formation of magnetite. Mothersole et al. (2017) used NC serpentinites as proxies of mantle wedge serpentinites and compared them with those from the $15^{\prime} 20^{\circ} \mathrm{N}$ fracture zone in the Mid-Atlantic Ridge to evaluate the effect of hydrothermal alteration on a budget of major and minor elements in the two different geodynamic settings (Mothersole et al. 2017). They concluded that serpentinization was nearly identical in the two environments, except more oxidized $\mathrm{Fe}$ as well as enrichments in $\mathrm{Cl}, \mathrm{S}$, and $\mathrm{C}$ in abyssal serpentinites compared to the forearc serpentinites. Serpentine-bearing faults were extensively studied i) to characterize their kinematics and the mechanisms of NC ophiolite emplacement on the continental basement (Gautier et al. 2016; Quesnel et al. 2016b), and ii) to constrain the carbonation and silicification of the serpentinite sole in relation to meteoric fluid percolation (Quesnel et al. 2016a; 2013; Ulrich et al. 2014) and iii) to understand the formation of secondary Ni-rich phyllosilicates, mostly talc-like phases, in serpentine-filled fractures at the top of the ophiolite (Cathelineau et al. 2016; 2015; Fritsch et al. 2016; Muñoz et al. 2019). High temperature, slab-derived fluids are proposed for the origin of syntectonic tremolite-antigorite veins, which are widespread in the Peridotite Nappe (Cluzel et al. 
2019). But the source and nature of fluids in equilibrium with the main serpentinization episode that affected the whole ophiolite remains, however, unconstrained.

\section{MATERIALS AND METHODS}

\section{Sampling and analytical strategies}

A collection of 30 samples, collected from five different massifs (the Massif du Sud, Kopeto, Koniambo, Tiébaghi and Poum), includes serpentinized harzburgites, lherzolites and dunites referred to as "upper serpentine" hereafter, as well as serpentinites from the sole of the Peridotite Nappe. They represent most rock types and serpentine occurrences of the NC ophiolite.The serpentinites were characterized by: 1) Raman spectroscopy, to identify serpentine species, 2) major and trace element chemistry of primary minerals and serpentines crystals, to evaluate the chemical mobility during fluid-rock interactions, 3) oxygen and hydrogen isotope geochemistry of each serpentine variety to discuss the source of fluids involved in the serpentinization processes.

\section{Raman Spectroscopy}

Raman spectra were acquired at ENS Lyon (France) using a Horiba Jobin-Yvon LabRam HR800 spectrometer and a visible ionized argon laser source with a wavelength of $514 \mathrm{~nm}$. Output laser power was $100 \mathrm{~mW}$, and measurements were performed using an Olympus lens of 100x to focus the laser beam onto an area that was $1 \mu \mathrm{m}$ in diameter. Analyses were carried out on $30 \mu \mathrm{m}$ polished thin sections. Spectra result from the average of 5 acquisitions of 10-20 s for each point measured to optimize the signal/noise ratio. Raman spectra were recorded in two spectral intervals: $200-1250 \mathrm{~cm}^{-}$ ${ }^{1}$ for structural bonding characterization and $3550-3800 \mathrm{~cm}^{-1}$ for the characterization of hydroxyl groups. Serpentine species were mainly identified by comparing spectra with those already published (Auzende et al. 2004; Lemaire 2000), focusing on the $\mathrm{OH}$ stretching range.

\section{Mineral Chemistry}

Electron microprobe analyses of minerals were carried out with a Cameca SX 100 at Service Commun de Microscopie Électronique et de Microanalyses (SCMEM, Nancy, France). All analyses of major elements, $\mathrm{Na}, \mathrm{Mg}, \mathrm{Al}, \mathrm{Si}, \mathrm{K}, \mathrm{Ca}, \mathrm{Ti}, \mathrm{Cr}, \mathrm{Mn}, \mathrm{Fe}, \mathrm{Ni}$, were made against natural and synthetic mineral standard: albite ( $\mathrm{Si}, \mathrm{Na})$, corundum $(\mathrm{Al})$, andradite $(\mathrm{Ca})$, olivine $(\mathrm{Mg})$, hematite $(\mathrm{Fe}), \mathrm{MnTiO}_{3}$ (Mn, $\mathrm{Ti}), \mathrm{NiO}(\mathrm{Ni})$, orthoclase $(\mathrm{K})$, with the exception for serpentine measurements for which $\mathrm{Mg}$ was calibrated using natural clinochlore. Acceleration voltage and beam current were $15 \mathrm{kV}$ and 12 $\mathrm{nA}$, respectively, the counting time was $10 \mathrm{~s}$, and standard correction procedures were applied. The beam diameter was focused to $1 \mu \mathrm{m}$. Total Fe content is calculated on a divalent basis, as FeO. Structural formulae were calculated based on of the following number of oxygens: olivine, 4; 
pyroxene, 6; lizardite, chrysotile and polygonal serpentine, 7. Antigorite has a general formulae $\mathrm{Mg}_{3 \mathrm{~m}}$ ${ }_{3} \mathrm{Si}_{2 \mathrm{~m}} \mathrm{O}_{5 \mathrm{~m}}(\mathrm{O} . \mathrm{H} \text {. })_{4 \mathrm{~m}-6}$ that differs from the idealized serpentine formula $\mathrm{Mg}_{3} \mathrm{SiO}_{5}(\mathrm{OH})_{4}$ by a minor $\mathrm{Mg}(\mathrm{OH})_{2}$ depletion, $m$ being the number of tetrahedra along an entire wavelength. Structural formulae for antigorite were calculated based on $\mathrm{m}=17$.

$\mathrm{Fe}^{2+}$ and $\mathrm{Fe}^{3+}$ contents in serpentine were calculated using the approach described by Beard and Frost (2017). Thus, in the $\left(\mathrm{Mg}+\mathrm{Fe}_{\mathrm{T}}\right)$ pfu vs. $(\mathrm{Si}+\mathrm{Al})$ pfu space, the microprobe analyses of serpentine lie along a linear trend that extends from pure $\mathrm{Mg}$ serpentine (lizardite/chrysotile or antigorite) to brucite $\left(\mathrm{Mg}(\mathrm{OH})_{2}\right)$. The trend towards brucite is a consequence of extremely fine-grained serpentinebrucite intergrowths. According to Beard and Frost (2017), the deviation of a serpentine analysis from the brucite trend reflects the stoichiometric effects of ferric iron substitutions in the crystal chemistry of serpentine. Here, a full dioctahedral substitution is assumed, meaning that ferric iron is accommodated in the serpentine structure by substitution for divalent cation plus the addition of a vacancy in the octahedral sheet. In this case, a serpentine that integrates a significant amount of ferric iron would deviate from the brucite trend, showing lower $\left(\mathrm{Mg}+\mathrm{Fe}_{\mathrm{T}}\right)$ pfu at a given $(\mathrm{Si}+\mathrm{Al}) \mathrm{pfu}$. Considering that this deviation is only caused by ferric iron substitution, the following equation provides $\mathrm{Fe}^{3+}$ pfu:

$$
F e^{3+}=-x \times(S i+A l)+7-\left(M g+F e_{T}\right)
$$

where $x$ is the ideal number of Si cations when the serpentine formula is calculated for seven oxygens (i.e., 2 in lizardite/chrysotile and 2.05 in antigorite).

A High-Resolution Laser Ablation Inductively Coupled-Plasma Mass Spectrometer (HR-LAICP-MS) at the Geosciences Ocean laboratory (Brest, France) composed of a $193 \mathrm{~nm}$ MicroLas CopexPro Coherent coupled with an Element II ICP-MS has been used for trace element analyzes. Laser ablations were performed with a constant $5 \mathrm{~Hz}$ pulse rate, with an ablation crater of 90 to 120 $\mu \mathrm{m}$ in diameter. The number of pulses was 200 , which is sufficient to form a long and stable signal for integration. The ablated material is transported using a constant He flow and mixed with Ar in a cyclone coaxial mixer before entering the ICP torch and being ionized. The ions are then sampled, accelerated and focused before being separated and analyzed in the mass spectrometer. ${ }^{29} \mathrm{Si}$ content — known from prior electron microprobe analyses — was used as internal standard and concentrations were calibrated against the NIST 612 rhyolitic glass using reference values from Pearce et al. (1997). Data reduction was carried out by using SILLS software, following the standard methods of Longerich et al. (1996). Detection limits were between $<1$ and $60 \mathrm{ppb}$ for most trace elements, <0.5 ppm for B, Li, Mn, Co, Ni, As and between 1 and 50 ppm for $\mathrm{Mg}, \mathrm{Ca}$, Ti considering a spot size of $120 \mu \mathrm{m}$. 


\section{Stable isotope measurements}

Stable oxygen and hydrogen isotope compositions were measured from separated serpentine fragments at the Stable Isotope Laboratory at the University of Lausanne. Separated powders were obtained by micro-drilling using a drill of $500 \mu \mathrm{m}$ of diameter for the largest veins of antigorite and chrysotile. A smaller drill of $100 \mu \mathrm{m}$ of diameter was used to sample the mesh core of lizardite. Serpentine samples were then purified from magnetite grains by using a hand-held magnet and potential denser primary minerals were separated by settling in water. Oxygen isotopes were measured according to a method adapted after Sharp (1992). Between 1 and $2 \mathrm{mg}$ of powder are loaded in a $\mathrm{Pt}$ sample holder and heated with a $\mathrm{CO}_{2}$-laser under a $\mathrm{F}$ atmosphere and a pressure of 50 mbar. The liberated oxygen is analyzed as O on a Finnigan MAT 253 mass spectrometer. Hydrogen isotope were measured by applying the method of Sharp et al. (2001). Between 0.5 and $1 \mathrm{mg}$ of sample powder is loaded in a tin capsule and reduced by reaction with glassy carbon at $1450^{\circ} \mathrm{C}$ in a helium carrier gas-producing $\mathrm{H}$ and CO. Produced gases are separated in a gas chromatograph and analyzed in a Finnigan MAT Delta Plus XL mass spectrometer configured to make hydrogen isotope analyses in continuous flow mode. Results are given in the standard $\delta$-notation, expressed relative to $\mathrm{V}_{\text {SMOW }}$ in permil (\%). Replicate oxygen isotope analyses of the standards (UWG-2 garnet) yielded an average precision of $\pm 0.25 \%$ for $\delta^{18} \mathrm{O}$ values. The precision of the $\mathrm{G} 1$ biotite in-house standards for hydrogen isotope analyses was $\pm 2 \%$.

\section{RESULTS}

\section{Serpentine petrography}

In agreement with the work of Orloff (1968), whereas the degree of serpentinization is moderate to high throughout the ophiolite ( $>50 \%$, "facies normal", Figure $\mathbf{2 a}, \mathbf{b}$ ), it is close to $100 \%$ near the base, giving to the rock a typical dark color ("facies de base"; Figure 2c). Locally, near the top of the massifs, the degree of serpentinization is less than $10 \%$ ("facies superieur"). There, serpentine occurs along fracture walls and also forms mm-thick black veins pervasively surrounding preserved grains of olivine and pyroxene.

The base of the ophiolite consists of a schistose and intensely brecciated serpentinite sole of 20 $\mathrm{m}$ to $300 \mathrm{~m}$ thick. Breccias are composed by $\mathrm{mm}$ to $\mathrm{dm}$-scale blocks (phacoids) of totally serpentinized peridotite embedded in a matrix of sheared serpentinite. Several generations of serpentine can be identified even at naked eye: massive serpentinite is crosscut by $\mathrm{mm}$ to $\mathrm{cm}$-thick, yellow to light-green serpentine veins (Figure 2d). These veins are systematically surrounded by dark seams of magnetite and the overall is frequently crosscut by mm-thick fibrous veins, the latter being occasionally replaced by veins of greenish to white serpentine (Figure 2e, f). This greenish to 
white serpentine may also compose large amounts of the breccia matrix. In thin section, the latest generations of serpentine occur almost exclusively as limited domains or veins formed after microfracture infilling (Figure 3b, c, d). Larger domains of replacement can be found, but they usually correspond to the strongly deformed area where secondary serpentine composes the breccia matrix.

In the less serpentinized samples, serpentinization starts at the boundaries of olivine grains and along micro-fractures (Figure 3). It progressively extends from the rim to the core of the grains as the serpentinization degree increases, giving the rock a typical mesh texture (see S1 in Figure 3a). In general, olivine is strongly affected by serpentinization, while orthopyroxene remains relatively preserved or develop bastite rims around fresh cores. Iron released during serpentinization crystallized as magnetite rimming olivine grains and along $\mathrm{mm}$-scale fractures, forming dark seams (Figure 3a).

Six generations of serpentine have been identified in the sole (S1-S6 in Figure 3). The first generation of serpentine after the primary mesh texture (S1) forms homogeneous domains that display the same grey color as the mesh texture under cross-polarized light (S2, Figure 3b, d). Black veins of magnetite identical to those observed in the mesh texture are present in S2, and extend parallel to the S2 borders. The limits of the S2 domain are diffuse, suggesting progressive replacements of the mesh texture $\mathrm{S} 1$. Both serpentine generations are closely associated with $\mu \mathrm{m}$ to mm-thick veins of serpentine of a characteristic bluish-grey color under cross-polarized light (S3, Figure 3b, c, d). S3 veins are made of decussate blades of tens of micrometers in size, giving these veins a typical interlocking texture. The borders of S3 veins are marked by the accumulation of magnetite grains, both inside and outside the veins. S4 veins occasionally crystallize in tension gashes, similarly to S5 veins and exhibit transitional texture between the decussate blades of S3 and the fibrous habitus that characterizes S5. Fibers can reach $\sim 200 \mu \mathrm{m}$ in size and have a grey to yellow birefringence under cross-polarized light (Figure 3b, c). They are commonly oriented perpendicularly to the vein edges. The latest serpentine generation (S6) occurs as replacement of previous serpentine generations, forming veins (Figure 3c) or covering large domains that form the matrix of breccias as shown by Ulrich et al. (2014) and Quesnel et al. (2016b).

\section{Nature of serpentine polymorphs}

The typical Raman spectra for the different generations of serpentine (i.e., from S1 to S6, as previously described) are displayed in Figure 4. Their specific spectral signatures allow identifying serpentine species (Figure 4; Auzende et al. 2004; Lemaire 2000). Except for minor changes in the low wavenumber region, the discrimination and identification of serpentine minerals are mainly based on the $\mathrm{OH}$ stretching bands located in the range $3600-3750 \mathrm{~cm}^{-1}$. Lizardite characterized by peaks at 
3685 and $3706 \mathrm{~cm}^{-1}$, is the most abundant variety, forming the $\mathrm{S} 1$ and $\mathrm{S} 2$ generations. In contrast, the typical Raman spectrum obtained for S3 veins corresponds to antigorite, with characteristic peaks at 3670 and $3699 \mathrm{~cm}^{-1}$. S5 perfectly matches with the spectral signature of chrysotile, and S4 corresponds to a mixture of antigorite (S3) and chrysotile (S5). Finally, the serpentine S6 is identified as polygonal serpentine, characterized by a weak band at $3648 \mathrm{~cm}^{-1}$ and a doublet at 3690 and $3697 \mathrm{~cm}^{-1}$ (Cathelineau et al. 2016).

\section{Chemistry of primary minerals}

The representative compositions in major and trace elements of primary minerals and each serpentine variety identified are presented in Tables 1 and 2 . The supplementary table $\mathrm{S} 1$ provides all the data. Standard deviations are $2 \sigma$. Analyses of the primary minerals are consistent with those previously published for the NC peridotites (Frost et al. 2013; Mothersole et al. 2017; Pirard et al. 2013). Olivine is Fo91 (Figure 5) and has a $\mathrm{NiO}$ content of $\sim 0.4$ wt.\% ( $\mathrm{Ni}=0.1 \mathrm{pfu}$ ) and $\mathrm{MnO}$ content of $\sim 0.16 \mathrm{wt} . \%$. Olivine is also characterized by an extreme depletion in trace elements so that they are usually close, or below, the detection limit. High-field strength elements (HFSE) have Primitive Mantle (PM)-normalized concentrations varying between $10^{-3}$ and $10^{-1}$ (Figure 6). Orthopyroxene is mainly enstatite and has a constant $\mathrm{Mg \#}$ similar to olivine (0.91). $\mathrm{CaO}$ content ranges between 0.42 and 2.79 wt. \% with an average value of 1.06 wt. \% ( $\mathrm{Ca}=0.04 \mathrm{pfu}) . \mathrm{Al}_{2} \mathrm{O}_{3}$ and $\mathrm{Cr}_{2} \mathrm{O}_{3}$ have concentrations ranging between 2.27 and $4.51 \mathrm{wt}$. $\%$ and 0.56 and $0.88 \mathrm{wt}$. \%, respectively, and a corresponding $\mathrm{Cr} \#$ of $\sim 0.12$ and down to 0.09 , reflecting a high degree of depletion of the peridotite. PM-normalized trace element patterns show that orthopyroxene is strongly depleted in light rare-earth elements (LREE), with $\mathrm{Ce}_{N} / \mathrm{Yb}_{\mathrm{N}}<0.05$. Clinopyroxene is diopside and is mainly present in spinel and plagioclase lherzolite, although some occurrences may be observed in harzburgite, mostly from exsolution in orthopyroxene. Clinopyroxene is characterized by slightly higher $\mathrm{Mg \#} \mathrm{(} \mathrm{0.93)} \mathrm{and}$ $\mathrm{Al}_{2} \mathrm{O}_{3}$ of $\sim 4.16$ wt. \% (Al=0.2 pfu) and $\mathrm{Cr}_{2} \mathrm{O}_{3}$ of 0.94 wt.\% (Cr\# 0.13). PM-normalized trace element patterns show a strong fractionation of LREE relative to heavy $(\mathrm{H}) \mathrm{REE}\left(\mathrm{Ce}_{\mathrm{N}} / \mathrm{Yb}_{\mathrm{N}}<0.01\right)$ and a nearly flat HREE pattern $\left(\mathrm{Dy}_{\mathrm{N}} / \mathrm{Yb}_{\mathrm{N}} \sim 0.8\right)$. Slight $\mathrm{Sr}$ and Eu anomalies are observed and reflect equilibrium with plagioclase.

\section{Chemistry of serpentine}

Lizardite replacing primary minerals in the upper parts of the massif (upper serpentines) has been divided in four types: lizardite after olivine (i.e. in the mesh core), lizardite in the mesh rim, lizardite after orthopyroxene and lizardite after clinopyroxene. All have $\mathrm{H}_{2} \mathrm{O}$ content of $\sim 13$ wt. \%, which is consistent with the hydroxyl stoichiometry of lizardite. Lizardite after olivine shows rather homogeneous compositions with 41 wt. $\% \mathrm{SiO}_{2}$ and $\mathrm{MgO}$ ( $\mathrm{Si}=2.0 \mathrm{pfu}, \mathrm{Mg}=2.9 \mathrm{pfu}$ ) and $\sim 4$ wt. \% 
$\mathrm{FeO}\left(\mathrm{Fe}^{2+}=0.2 \mathrm{pfu}\right)$. Compared to olivine, mesh cores have higher $\mathrm{Al}_{2} \mathrm{O}_{3}$ content $(\sim 0.3$ wt. \%) and lower $\mathrm{NiO}$ content ( $\sim 0.2$ wt. \%). Mesh rims are characterized by lower $\mathrm{SiO}_{2}$ and $\mathrm{MgO}$ contents (38 wt. $\%$ and 37 wt. $\%$, respectively). FeO content is higher $\left(>10\right.$ wt. $\left.\%, \mathrm{Fe}^{2+}=0.5 \mathrm{pfu}\right)$ and may reflect the presence of minute grains of magnetite in the mesh rims. Bastite contains 38 to $42 \mathrm{wt} . \% \mathrm{SiO}_{2}$, and is usually characterized by lower $\mathrm{Si}$ at a given $\mathrm{Mg}+\mathrm{Fe}_{\mathrm{T}}$ compared to lizardite after olivine, and displays higher $\mathrm{Cr}$ and $\mathrm{Al}$ contents. $\mathrm{Mg \#}$ varies between 0.91 and 0.97 , with an average of 0.92 (Figure 5). Bastites formed either after orthopyroxene or clinopyroxene do not show any difference in the major element concentrations. Regarding the Fe oxidation state in upper serpentines, our estimates show that $\mathrm{Fe}$ is mostly divalent $\left(\mathrm{Fe}^{3+} / \mathrm{Fe}_{\mathrm{T}}<0.1\right.$, Figure 5d), consistently with previous estimates made by Beard and Frost (2017).

Primitive Mantle normalized trace element patterns of upper serpentines are presented in Figure 6. Despite some slight differences (particularly some enrichments in large ion lithophile elements, LILE), PM-normalized trace element patterns of serpentines match well those of primary minerals. Minor and trace elements in lizardite after olivine is highly depleted (Ti: 10.0-85.8 ppm; Mn: 125-1059 ppm; Co: 18.7-81.1 ppm; Y: 0.060-0.375 ppm), with a strong fractionation between LREE and HREE $\left(0.008<(\mathrm{Ce} / \mathrm{Yb})_{\mathrm{N}}<0.132\right)$. Lizardite after orthopyroxene is slightly less depleted in minor and trace elements (Ti: 158-174 ppm; Mn: 568-635 ppm; Co: 26.8 ppm; Y: 0.907-0.994 ppm) but still shows LREE depleted patterns and strong LREE/HREE fractionation $\left(0.02<(\mathrm{Ce} / \mathrm{Yb})_{\mathrm{N}}<0.162\right)$ similar to lizardite after olivine. LREE are depleted in serpentine after clinopyroxene. Elements such as Y (7.81 ppm), Ti (2163 ppm), Mn (1460 ppm) and Co (67.4 ppm) are enriched compared to lizardite after olivine and orthopyroxene. Only one occurrence of lizardite after clinopyroxene was found, confirming that the clinopyroxene is more frequently transformed into amphibole (tremolite) than serpentine during the hydration processes. Regarding fluid-mobile elements (FME), upper serpentines are enriched in B (4.71-24.3 ppm), Sb (0.007-0.016 ppm) and U (0.854-2.74 ppm) and depleted in Li and Sr with respect to Depleted Mantle (DM) values (Figure 7). More specifically, $\mathrm{Pb}$ and $\mathrm{Sr}$ concentrations are similar to those previously published for $\mathrm{NC}$ serpentinized peridotites (Secchiari et al. 2016; 2019; Ulrich et al. 2010), and overlap the fields of abyssal serpentinites and subducted serpentinites with some sedimentary contributions. Upper serpentinites display $\mathrm{B}, \mathrm{Li}$ and $\mathrm{Sb}$ concentrations lower than those of other serpentinites worldwide (Figure 7). Arsenic is always below the detection limits.

In the serpentinite sole, all serpentine species display homogeneous major and trace element compositions. They contain $\sim 44$ wt. $\% \mathrm{SiO}_{2}(\mathrm{Si}=2.0 \mathrm{pfu}), 40 \mathrm{wt} . \% \mathrm{MgO}(\mathrm{Mg}=2.8 \mathrm{pfu}), \sim 13$ wt. $\%$ $\mathrm{H}_{2} \mathrm{O}$ and they are characterized by very low $\mathrm{FeO}(\sim 2$ wt.\%, $\mathrm{Fe} \leq 0.1 \mathrm{pfu})$ and $\mathrm{Al}_{2} \mathrm{O}_{3}(<0.1 \mathrm{wt} . \%, \mathrm{Al}$ $<0.005 \mathrm{pfu}$; Figure 5) and very high $\mathrm{Mg \#} \mathrm{(} \mathrm{0.98)} \mathrm{compared} \mathrm{to} \mathrm{upper} \mathrm{serpentines.} \mathrm{Calculated}$ $\mathrm{Fe}^{3+} / \mathrm{Fe}_{\mathrm{T}}$ ratio shows that serpentines from the sole integrate significant amounts of ferric iron: On 
average, lizardite and chrysotile have $\mathrm{Fe}^{3+} / \mathrm{Fe}_{\mathrm{T}}$ ratio of $\sim 0.2$, antigorite, 0.35 , and polygonal serpentine, 0.7 (up to 1). They also show HFSE depletion similar to that described in upper serpentines. However, they are slightly more depleted in HREE and significantly more enriched in LREE, except Ce which has a similar concentration to that of moderately serpentinized NC peridotites. Serpentines from the sole display a strong Ce negative anomaly $(\mathrm{Ce} / \mathrm{Ce} *=0.009-0.739$, Figure 7). They also display enriched concentrations in FME relative to upper serpentines (B: 2.138.52 ppm; Sb: 0.005-0.057 ppm; Li: 0.054-0.543; Cs: 0.004-0.022; Rb: 0.014-0.275 ppm; Ba: 0.0660.952 ppm; Pb: 0.002-0.133; Sr: 0.202-4.05 ppm) with a pronounced U positive anomaly (U: 0.0010.043 ppm; Figure 6). Similarly to upper serpentines, As concentrations in the serpentinite sole were too low to be determined (Table 2).

\section{$O$ and $\mathrm{H}$ stable isotope composition}

The $\delta^{18} \mathrm{O}$ and $\delta \mathrm{D}$ values of fresh peridotites are 5.5\%o and $-70 \%$ respectively, which are consistent with mantle rock compositions (Deloule et al. 1991; Eiler 2001). Serpentines display a wide range of $\delta^{18} \mathrm{O}$ values from $1.7 \%$ to $13.9 \%$. In contrast, $\delta \mathrm{D}$ values are quite homogeneous $(-107$ to $-88 \%$ ). No systematic difference can be observed between serpentine species.

The upper serpentines (i.e., lizardite) display a narrow range of isotopic compositions: $5.4 \%<<\delta^{18} \mathrm{O}<6.9 \%$ and $-103 \%$ o $<\mathrm{D}<-97 \%$. In the serpentinite sole, the $\delta^{18} \mathrm{O}$ and $\delta \mathrm{D}$ values of lizardite are somewhat broader: $\delta^{18} \mathrm{O}_{\text {liz }}=2.2$ to $5.7 \%$ and $\delta \mathrm{D}_{\text {liz }}=-107$ to $-97 \%$. The whole range of values including other serpentine species from the sole is 1.7 to $12.2 \%$ for oxygen, -107 to $-88 \%$ for hydrogen. Two samples (Ti 51a-1, -2, Poum 4-6, -2, -3) have traces of amorphous silica, and also the highest $\delta^{18} \mathrm{O}$ values. Such high values are likely due to amorphous silica, which has high $\delta^{18} \mathrm{O}$ values around 30\%o (Quesnel et al. 2016a). For this reason, these data will not be considered further in the following discussion. The isotopic compositions of serpentines are thus assumed to range between 1.7 to $7.9 \%$ for $\delta^{18} \mathrm{O}$, and from -107 to $-88 \%$ for $\delta \mathrm{D}$.

\section{DISCUSSION}

\section{Deciphering the source of serpentinization fluids and conditions of serpentinization from the} serpentine chemistry: a new modeling approach

The New Caledonia serpentines plot away from the field of oceanic serpentines defined in the literature (Sakai et al. 1990; Wenner and Taylor 1973), therefore excluding the involvement of seawater in the serpentinization process (Figure 8a). Some trace element concentrations also confirm this inference (Figure 7), since abyssal serpentines are usually characterized by a high U/Th ratio, attributed to seawater interaction with peridotite (Deschamps 2010; Frisby et al. 2016). U and Th are 
highly depleted in the mantle (e.g., Salters et al. 2002), but U is enriched in seawater relative to Th (Chen et al. 1986), leading to a significant fractionation between these elements when seawater is involved in serpentinization process. The Ce negative anomaly $(\mathrm{Ce} / \mathrm{Ce} *<1$, with $\mathrm{Ce} / \mathrm{Ce} *$ equals to $\left.\mathrm{Ce}_{\mathrm{N}} /\left[\left(\mathrm{LaN}^{*} \operatorname{Pr}_{\mathrm{N}}\right)^{1 / 2}\right]\right)$ is typical of the seawater where $\mathrm{Ce}^{3+}$ is oxidized tino the less soluble $\mathrm{Ce}^{4+}$ (Elderfield and Greaves 1982). Low Ce/Ce* is also a common feature in abyssal serpentines (Delacour et al. 2008; Frisby et al. 2016; Rouméjon et al. 2015). Frisby et al. (2016) have recently shown that seawater influences the LREE budget of serpentine through the addition of La and Pr, and that $\mathrm{Ce} / \mathrm{Ce} *$ decreases in abyssal serpentines with increasing U/Th. NC serpentines, more specifically those from the serpentinite sole, are characterized by high U/Th and low Ce/Ce*ratios compared to moderately serpentinized NC peridotites (Figure 7). However, U/Th ratio never exceeds 10 in our samples whereas it is >>10 in abyssal serpentines (up to 10,000). Also, most of our samples display much larger Ce negative anomalies than that of abyssal serpentines, thus providing additional evidence that seawater was unlikely involved in the formation of NC serpentines.

Serpentine with $\delta \mathrm{D}$ values as low as $-100 \%$ o have been identified in other places worldwide, forming the "Ophiolite serpentines" field defined by Wenner and Taylor (1973) where NC serpentines plot (Figure 8a). These Ophiolite serpentines are commonly assumed to result from the interaction of peridotite with meteoric or metamorphic fluids either during obduction or during exhumation and retrograde re-equilibration of the peridotites (Früh-Green et al. 1996; 2001; Kyser et al. 1999; O’Hanley 1996). Typically, very low $\delta \mathrm{D}$ values for serpentine minerals (<-100\%) are attributed to late serpentinization events due to the circulation of meteoric waters under subsurface conditions. On the other hand, $\delta \mathrm{D}$ values in the range of -100 to $-70 \%$ are better explained by the presence of composite fluids (Burkhard and O`Neil 1988; Früh-Green et al. 2001).

The $\mathrm{O}$ and $\mathrm{H}$ isotope compositions of a given serpentine depend on three main parameters: 1) the isotopic composition of the serpentinizing fluid $\left(\delta^{18} \mathrm{O}_{\text {fluid }}\right.$ and $\left.\left.\delta \mathrm{D}_{\text {fluid }}\right), 2\right)$ the serpentinization temperature (T), and 3) the water-rock ratio (W/R) during the reaction. The complex relationships between these three parameters on the one hand, and the isotopic fractionation factors on the other hand, have been characterized experimentally and from the study of natural samples (e.g. Saccocia et al. 2009; Sakai and Tsutsumi 1978; Savin and Lee 1988; Wenner and Taylor 1973; Zheng 1993). The isotopic compositions of serpentinizing fluids may be calculated using calibrated serpentine-water isotopic fractionation factors, and assuming W/R values and temperature (e.g., Alt et al. 2012; Alt and Shanks Iii 2006; Früh-Green et al. 2001; Kyser et al. 1999; Rouméjon et al. 2015; Sakai et al. 1990; Thakurta et al. 2009). Alternatively, W/R can be determined if the composition of the serpentinizing fluid is known (Agrinier and Cannat 1997; Alt et al. 2007; Burkhard and O'Neil 1988; Magaritz and Taylor 1974; Rouméjon et al. 2015; Wenner and Taylor 1973). Conversely, the approximative temperature of serpentinization can be estimated by using the serpentine-magnetite 
geothermometer, based on the oxygen isotope fractionation between these two cogenetic minerals (Wenner and Taylor 1971). Actually, this approach is somewhat unsatisfactory because it requires knowing or arbitrarily setting at least one of the parameters listed above. For example, in the oceanic context, serpentine fluids are relatively well constrained because they are either seawater or seawater modified by hydrothermal fluids (Agrinier and Cannat 1997). But for fluids derived from ancient lithospheric remnants, $\delta^{18} \mathrm{O}_{\text {fluid }}$ and $\delta \mathrm{D}_{\text {fluid }}$ are generally unknown and need to be assumed or calculated. It follows that the serpentine-magnetite geothermometer can hardly be used in the case of multiple serpentinization events since the related generations of magnetite are challenging to identify and separate.

In this study we developed a new approach based on Monte Carlo simulations to constrain the source of fluids in equilibrium with NC serpentines based on their oxygen and hydrogen isotope compositions. Figure 8 (b to d) shows the result of one million Monte Carlo simulations using the isotopic fractionation factors of Wenner and Taylor (1973) (as modified by O'Hanley 1996) for oxygen isotopes:

$$
1000 \ln \alpha_{\text {serpentine-water }}^{18}=1.69 \times 10^{6} / T^{2}-4.23
$$

and of Saccocia et al. (2009) for hydrogen isotopes:

$$
1000 \ln \alpha_{\text {serpentine-water }}^{D-H}=3.436 \times 10^{6} / T^{2}-34.736 \times 10^{3} / T+21.67
$$

where $\mathrm{T}$ is the temperature in Kelvin. It should be noticed that the use of oxygen isotope fractionation factors from Saccocia et al. (2009) provides quite similar results to those of Wenner and Taylor (1971) in the temperature range of $250-450^{\circ} \mathrm{C}$. However the serpentine--water ${ }^{18} \mathrm{O}-{ }^{16} \mathrm{O}$ fractionation factor of Wenner and Taylor (1971) is applicable for a wide range of temperature, contrarily to the experimental approach of Saccocia et al. (2009) whose fractionation factor was calibrated for temperatures $>250^{\circ} \mathrm{C}$. As a consequence, the use of the Wenner and Taylor fractionation factor was found more consistent with calculating the $\delta^{18} \mathrm{O}$ composition of serpentinizing fluids when no other constraint on serpentinization temperature is available.

The $\mathrm{O}$ and $\mathrm{H}$ isotope compositions of a serpentine can be calculated by applying Sheppard et al. (1969) mass-balance equation:

$$
\delta_{\text {serpentine }}=\frac{\delta_{\text {mantle }}+W / R \times\left(\delta_{\text {fluid }}+1000 \text { ln } \alpha_{\text {serpentine-water }}\right)}{1+W / R}
$$


with $\delta_{\text {serpentine }}, \delta_{\text {mantle }}$ and $\delta_{\text {fluid }}$ are the $\mathrm{O}$ and $\mathrm{H}$ isotope compositions of the serpentine, the mantle and the serpentinizing fluid, respectively, W/R is the fluid-rock ratio and 1000ln $\alpha$ is the fractionation factor calculated with equations (2) and (3). Mantle values of $\delta^{18} \mathrm{O}=+5.5 \%$ and $\delta \mathrm{D}=-80 \%$ have been chosen for the composition of the starting material (Deloule et al. 1991; Eiler 2001). Other parameters are defined randomly for each simulation in the following ranges: $50<\mathrm{T}^{\circ} \mathrm{C}<450$, $0.13<\mathrm{WR}<1000,-40<\delta^{18} \mathrm{O}_{\text {fluid }}(\%)<40$ and $-200<\delta \mathrm{D}_{\text {fluid }}(\%)<20$ (see Figure 8). Although serpentine can be stable at temperature up to $\sim 700^{\circ} \mathrm{C}$, the temperature of serpentinization rarely exceeds $350{ }^{\circ} \mathrm{C}$ at spreading centers and $400-500^{\circ} \mathrm{C}$ in subduction zones (e.g., Evans 2004; Klein et al. 2013; Ulmer and Trommsdorff 1995). Low-temperature serpentinization remains poorly documented, even though some authors argued for serpentinization might occur at temperature lower than $80^{\circ} \mathrm{C}$ (e.g., Agrinier et al. 1995; Bonatti et al. 1984). Thus, a low-temperature threshold of $50^{\circ} \mathrm{C}$ was chosen arbitrarily. The range of fluid-rock ratios was chosen considering that 0.13 is the minimum ratio required to convert an olivine into a serpentine stoichiometrically, and $\delta_{\text {serpentine }}^{W R=1000} \approx$ $\delta_{\text {serpentine }}^{W R} . \delta_{\text {fluid }}$ thresholds were chosen so that almost all compositions of terrestrial fluids were covered (Hoefs 2009). In our modeling approach, a simulation is considered to be valid when the modeled serpentine displays $\delta^{18} \mathrm{O}$ and $\delta \mathrm{D}$ compositions that are in the range of $\mathrm{NC}$ serpentinites $\left(1.7 \%{ }_{0}<\delta^{18} \mathrm{O}<7.9 \%\right.$; $-107 \%<<\mathrm{D}<-88 \%$ ). Results are provided in supplementary materials and are presented in Figure 8: Figure 8b reports the calculated $\delta^{18} \mathrm{O}$ and $\delta \mathrm{D}$ compositions of fluids that are able to reproduce a serpentine that matches the $\mathrm{O}$ and $\mathrm{H}$ compositions of $\mathrm{NC}$ serpentines. Among 1 million random simulations, $\sim 6500$ were consistent with the $\mathrm{O}$ and $\mathrm{H}$ signatures of $\mathrm{NC}$ serpentines. Figure 8c and Figure 8d show, respectively, the calculated $\delta^{18} \mathrm{O}_{\text {fluid }}$ and $\delta \mathrm{D}_{\text {fluid }}$ as a function of the correspondent temperatures of serpentinization. Results of Monte-Carlo simulations show that fluids in equilibrium with NC serpentines extend between the meteoric water line and an area defined between $3 \%$ and $8 \%$ in $\delta^{18} \mathrm{O}$ and $-80 \%$ and $-60 \%$ in $\delta \mathrm{D}$ in which most of the results plot ( $40 \%$ of 6500 simulations, see the red, white cross-hatched area in Figure 8b). Fluids that fall into this area have interacted with the mantle at temperatures between $\sim 250^{\circ}$ and $430^{\circ} \mathrm{C}$ (the white cross-hatched areas in Figure 8c,d), while interactions with fluids showing negative $\delta^{18} \mathrm{O}$ and higher $\delta \mathrm{D}$ signatures (>-60\%o) occurred at lower temperatures $\left(100-200^{\circ} \mathrm{C}\right.$; Figure 8c, d). With a few exceptions, our calculations show that NC serpentines were formed at relatively high W/R (>1) (see Figure S1 in supplementary materials).

\section{Origin of NC serpentinites}

\section{From deep serpentinization...}

Based on the new petrological, mineralogical, geochemical and modeling data presented here, the chronology of serpentinization of NC peridotites would be as follows. First, the decreasing 
serpentinization degree from bottom to the top of the Peridotite nappe is good evidence for a fluid circulation mainly located at the base of the ophiolite. Since the NC ophiolite was in the forearc position for $\sim 20$ Ma before its obduction on the Norfolk Ridge, the most likely source of the fluids forming pervasive lizardite S1 would come from dehydration of the subducting slab. As our results fall into the Alpine Ophiolite-type field of Wenner and Taylor (1973), they are consistent with this assumption. Consequently, three potential sources of fluids present in the recycled oceanic lithosphere can contribute to hydrating the mantle wedge: the altered oceanic crust (AOC), the subducted sediments and the subducted abyssal serpentinites. The fluids in equilibrium with all of these components have distinct signatures in trace elements and stable isotopes that also sharply differ from the composition of the mantle wedge (Eiler et al. 1998; Kodolanyi et al. 2012; Peters et al. 2017). One of the best examples documented worldwide is provided by the formation of serpentine mud volcanoes along the Marianna Trench (Fryer 1992). The geodynamics in this region approximates the one assumed for the South Loyalty Basin at the subduction time, and the occurrence of serpentinite seamounts provide a unique window for studying fluid circulations into the forearc mantle. Alt and Shanks III (2006) used typical $\delta^{18} \mathrm{O}$ and $\delta \mathrm{D}$ values for the AOC, oceanic sediments, and abyssal serpentinites to predict the isotopic compositions of fluids in equilibrium with each subducted component, and determine the source of serpentinizing fluids in the Marianna forearc mantle. In their modeling, they assumed that the metasomatized basaltic basement has $\delta^{18} \mathrm{O}=+8$ to $+11 \%$ and $\delta \mathrm{D}=-90$ to $-120 \%$ (Alt 2003), and used a simplified AOC mineralogy with $49 \%$ albite, $49 \%$ chlorite and $2 \%$ calcite. The dehydration of metabasalts having these isotopic compositions and mineralogy would produce, therefore, fluids with $\delta^{18} \mathrm{O}$ values of +2 to $+8 \%$ (up to $+10 \%$ at $400{ }^{\circ} \mathrm{C}$ ) and $\delta \mathrm{D}$ values of $-50 \%$ o to $-90 \%$. Similarly, the authors calculated higher $\delta^{18} \mathrm{O}(+12$ to $+16 \%$ ) and $\delta \mathrm{D}\left(-20\right.$ to $-40 \%$ ) values for sediment-derived fluids and $\delta^{18} \mathrm{O}$ and $\delta \mathrm{D}$ in the range of +5 to $+9 \%$ and -5 to $-30 \%$ respectively for serpentine-derived fluids at $\sim 200-350^{\circ} \mathrm{C}$ (Figure $8 \mathbf{b}$ ). By comparison, the main $\mathrm{O}$ and $\mathrm{H}$ isotope values calculated for fluids in equilibrium with $\mathrm{NC}$ serpentinites (the red, white cross-hatched area in Figure 8b) are consistent with fluids coming from the dehydration of an AOC. On the contrary, neither sediment-derived fluids nor serpentine-derived fluids fit our modeled serpentinizing fluids. Our simulations also predict that AOC-derived fluids interacted with the forearc peridotites at temperatures of $250-430^{\circ} \mathrm{C}$ (Figure 8c, d). These temperatures are close to those of AOC dehydration usually proposed in forearc settings $\left(200-450^{\circ} \mathrm{C}\right.$; Alt and Shanks Iii 2006; Rüpke et al. 2004). Additionally, the maximum temperature of $430^{\circ} \mathrm{C}$ estimated by our simulations may be lowered to $\sim 350^{\circ} \mathrm{C}$ based on field observations: lizardite is commonly replaced by antigorite at temperature $>350^{\circ} \mathrm{C}$ in (supra)-subduction environments (Evans et al. 1976; Evans 2004; Ulmer and Trommsdorff 1995; 1999). This replacement has never been observed in the NC ophiolite, where 
lizardite is the dominant serpentine variety, while antigorite is mainly restricted to synkinematic crack seals (Cluzel et al. 2019; Quesnel et al. 2016b).

Regarding trace elements, the evolution of the mantle wedge composition interacting with slabderived fluids is evaluated by proposing a single-step process where the fluids that migrate from the descending slab are mixed with the overlying forearc mantle. Trace element concentrations of a slabderived fluid $\mathrm{C}_{\mathrm{f}}$ can be estimated by applying the following equation:

$$
C_{f}=\frac{C_{0} \times M}{F}
$$

where $\mathrm{C}_{0}$ is the concentration of an element in the subducted component (i.e., the AOC, the sediments or the serpentinites), $\mathrm{M}$ is the mobility (in percent) of an element during the dehydration of a subducted component, and $\mathrm{F}$ is the weight fraction of fluid extracted from the subducted component (Sano et al. 2001). All parameters used for the modeling of trace elements, references and results of calculations are summarized in Table 4. The weight fraction of fluids released from the AOC and sediments is assumed to be 1.5 and 3 wt.\% respectively, in agreement with estimates previously published (Peacock 1990; Rüpke et al. 2004). The lizardite-antigorite transition in the subducting slab could have released fluids at temperatures below $350^{\circ} \mathrm{C}$ in the forearc subducted slab. Thus, pure $\mathrm{Mg}$ lizardite contains 13 wt. $\% \mathrm{H}_{2} \mathrm{O}$, while pure Mg-antigorite $(\mathrm{m}=17)$ only contains 12.3 wt.\% $\mathrm{H}_{2} \mathrm{O}$. Consequently, the weight fraction of serpentine-derived fluids was set to $\sim 0.7 \mathrm{wt} \%$. Data of element mobility during dehydration processes are taken from experimental studies on natural pelite for sediments (Aizawa et al. 1999), natural amphibolite for AOC (Kogiso et al. 1997; Sano et al. 2001) and natural antigorite for serpentinite (Tenthorey and Hermann 2004). U, Th, B and $\mathrm{Zr}$ are used because of their behavior during dehydration and their respective concentrations in the slab components: Th and $\mathrm{Zr}$ mobilities are rather low in hydrous fluids, while B is highly mobile. U mobility depends on its oxidation state: it is immobile in its reduced form $\mathrm{U}^{4+}$ while it is mobile in its oxidized form $\mathrm{U}^{6+}$ (Brenan et al. 1995). Actually, the high solubility of uranium in subduction zone fluids has been reported by several studies (e.g., Bailey and Ragnarsdottir 1994; Bali et al. 2010). All of these elements are enriched in sediments (Plank 2014) and depleted in the mantle (Salters and Stracke 2004; Secchiari et al. 2019). The U/Th ratio is low in sediments, but is roughly similar in AOC and abyssal serpentinites (Table 4). However, the U/Th ratio is more fractionated during serpentine dehydration than during AOC dehydration (Kogiso et al. 1997; Tenthorey and Hermann 2004). As a consequence, the U/Th ratio is higher in serpentine-derived fluids than in AOC fluids, and is the lowest in sediment-derived fluids (Figure 9). Subducted serpentinites have a high B/Zr ratio ( $>20)$, contrarily to subducted sediments and AOC, which are characterized by low $(<1)$ to very low $(<0.1) \mathrm{B} / \mathrm{Zr}$ ratios, respectively. Considering these ratios and the high mobility of $\mathrm{B}$ in fluids 
compared to $\mathrm{Zr}$, the addition of subduction zone fluids in the mantle wedge leads to an increase of $\mathrm{B} / \mathrm{Zr}$ ratio towards $\sim 50$ for AOC-derived fluids, $\sim 370$ for sediment-derived fluids and up to $\sim 8,200$ for serpentine-derived fluids. Consistently with the conclusions drawn from the stable isotope study, the trace element modeling suggests that NC upper serpentines were likely formed by the interaction with AOC-derived fluids, with nevertheless some addition of sediment-derived fluids $(<30 \%$, Figure 9). This result is consistent with the highly radiogenic strontium isotope compositions of some NC serpentines from which a metasedimentary contribution was inferred (Cluzel et al. 2019). The modeling also indicates that the amount of slab-derived fluids that interacted with NC peridotites in the forearc was low, in the range of $<0.1-3 \mathrm{wt} . \%$ (Figure 9). The amount of sediment-derived fluids in the mantle wedge was consequently in the order of 0.9 wt.\% or less. Such a low amount of sediment-derived fluids is unresolvable by our modeling approach based on stable isotopes (Figure 8). On the contrary, the $\mathrm{Sr}$ budget of sediments is high compared to the mantle so that a minute amount of sediments can buffer the $\mathrm{Sr}$ isotope system. These results together with the very low concentrations of As and $\mathrm{Sb}$, which are proxies of the sedimentary contribution in serpentine chemistry (Deschamps et al. 2013; Deschamps et al. 2011; Hattori and Guillot 2007), imply that the amount of subducted sediments was low at the time of forearc peridotite hydration. The limited influence of sedimentderived fluids in the serpentine signature is also inferred by the lack of sedimentary prism, the latter being replaced by slices of basaltic rocks (i.e., the future Poya Terrane) scrapped off the down going plate during the Eocene NE-dipping subduction of the SLB (Cluzel et al. 2001; 2012b). In Figure 9, the domain of the serpentinite sole is more widespread than that of upper serpentines, with some samples plotting away from the modeling trends. This could reflect the effects of a later episode of fluids circulation (see the next section below) rather than those of slab-derived fluids contribution.

The subduction inception occurring at (or near to) the ridge axis in the SLB led to the development of a forearc magmatic activity from 55 to $47 \mathrm{Ma}$ (Cluzel et al. 2006; 2016). During this period, thermal conditions in the forearc were high, causing the melting of the mantle wedge rather than its hydration. The continuous influx of fluids released from the dehydration of the oceanic crust of the subducting slab progressively cooled the forearc mantle, leading to the cessation of the forearc magmatism about $10 \mathrm{Ma}$ after subduction inception (Cluzel et al. 2012a; Cluzel et al. 2016; Ulrich et al. 2010; Whattam et al. 2008). This period was long enough to alter significantly the oceanic crust exposed at the seafloor (Staudigel et al. 1981) Then, the AOC entering the subduction zone releases fluids in the overlying mantle wedge. Such fluids finally cause the massive serpentinization of the future NC ophiolite (Figure 10a). It is worth noting that based on these results, no trace of oceanic serpentinization related to the opening of the SLB was identified so far. It is possible however that the serpentinized upper part of the upper plate (the Loyalty Basin) was removed early (i.e., soon after subduction inception) when the hot and buoyant lower plate had to force its way beneath the future 
Loyalty fore-arc. Such a feature could account for the absence of MORB-type basaltic crust on top

of the peridotites in the Massif du Sud and the occurrence of fore-arc cumulates directly overlying highly depleted harzburgites and dunites.

\section{...to (sub-) surface serpentinization.}

The development of multiple serpentine generations in the tectonic sole likely reflects changes in crystallization conditions, including the fluid composition and the formation events, both being connected with the tectonic history of the Peridotite Nappe. Consistently, the significant differences in the chemical compositions from S1 to S2 serpentines (e.g., increasing Mg\#, different trace element patterns) may reveal a change in the elemental budget of serpentinizing fluids. On the other hand, the transition from the lizardite-antigorite assemblage (S2-S3/S4) to chrysotile-polygonal serpentine (S5S6) without significant changes in the serpentine chemistry is in favour of a sole development under cooling temperatures. Our modeling approach of stable isotopes suggests that AOC-derived fluids alone cannot explain the formation of the serpentinite sole. Low temperature fluids $\left(\sim 100-250^{\circ} \mathrm{C}\right)$ of a meteoric origin can be considered (Figure 8b). The involvement of meteoric fluids is also suggested by major and trace element compositions of sole serpentines. The high $\mathrm{Fe}^{3+} / \mathrm{Fe}_{\mathrm{T}}$ ratio in serpentines from the sole (Figure 5) indicates a formation under more oxidizing conditions than in the upper system, which may be interpreted in term of formation depth.

Interestingly, Muñoz et al. (2019) showed that secondary serpentines, which are formed close to the surface by the circulation of meteoric fluids during the early stages of laterization display an increasing amount of ferric iron from lizardite $\left(\mathrm{Fe}^{3+} / \mathrm{Fe}_{\mathrm{T}}=0.4\right)$ to polygonal serpentine $\left(\mathrm{Fe}^{3+} / \mathrm{Fe}_{\mathrm{T}}=0.95\right) . \mathrm{Fe}^{3+} / \mathrm{Fe}_{\mathrm{T}}$ ratios in serpentines from the sole are very comparable to those measured in the regolith. Polygonal serpentine was also the latest serpentine variety to form and it has the

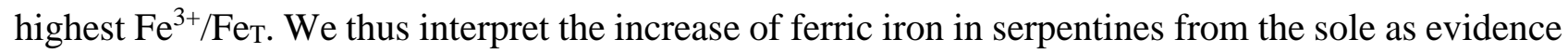
of their formation under near-surface conditions (i.e., low temperature, high $\mathrm{fO}_{2}$ ). The behavior of LREE provides additional proof of meteoric fluid involvement in the formation of the serpentinite sole. Serpentines from the serpentinite sole are LREE-enriched, except Ce. The exact opposite, i.e., LREE depletion and strong Ce positive anomaly (Figure 7), is observed in laterites on top of the NC regolith and is explained by the very low mobility of $\mathrm{Ce}^{4+}$ relative to all other REE (Ulrich et al. 2019). Also, the downslope migration of elements from the regolith can explain the high U/Th ratio in serpentines from the sole. Indeed, $U$ is mobile under oxidizing surface conditions, while Th is insoluble (e.g., Dequincey et al. 2002). As a consequence, U/Th ratio is lower in laterites than in the initial peridotite (Figure 7). Meteoric fluids may thus transport LREE, and potentially other FME, released during weathering. A high $\mathrm{U} / \mathrm{Th}$ ratio and a low $\mathrm{Ce} / \mathrm{Ce} *$ ratio in serpentine is therefore not necessarily a marker for the influence of seawater solely. 
Lateritization has been considered as rather early and was active during or slightly after the

ophiolite emplacement by Quesnel et al. (2013), based on a coupled isotopic and structural analysis of magnesite veins. Following our Monte-Carlo simulations, the $\mathrm{O}$ and $\mathrm{H}$ isotope signatures of the meteoric fluids involved during serpentinization $\left(\delta^{18} \mathrm{O}=-6 \pm 2 \%\right.$, $\delta \mathrm{D}=-40 \pm 10 \%$; Figure 8b) are comparable with present-day rainwater (Nicolini et al. 2016). The current discharge of $\mathrm{H}_{2}, \mathrm{CH}_{4}$, and $\mathrm{N}_{2}$-enriched hyperalkaline spring waters reveals active and low-temperature serpentinization at the base of the NC ophiolite (Deville and Prinzhofer 2016; Monnin et al. 2014). Thus, the serpentinization of the serpentinite sole was partly formed in response to the circulation of meteoric fluids during the late stages of its emplacement (Figure 10b). After the crystallization of lizardite 2 in microfracture networks, antigorite veins may have crystallized under moderate temperatures $\left(<250^{\circ} \mathrm{C}\right)$, and high deformation conditions, such as documented by Ribeiro Da Costa et al. (2008). Finally, as the obduction proceeded, the progressive cooling temperatures may have led to the replacement of antigorite into lower temperature species, such as chrysotile and polygonal serpentine, as shown by Quesnel et al. (2016b).

\section{CONCLUSIONS}

The new mineralogical and geochemical data presented here, on the serpentinites from the peridotite nappe and the sole of NC ophiolite, provide evidence for a polyphasic history of fluid-rock interactions. By using trace element concentrations and a new modeling approach based on Monte Carlo simulations applied on oxygen and hydrogen isotope compositions, we propose that the main serpentinization event (lizardite formation) mostly occurred during the NE-dipping subduction in the SLB due to slab dehydration and subsequent hydration of forearc mantle wedge (i.e., the future Peridotite Nappe). Also, our simulations shift serpentinization temperatures in the fore-arc mantle in the range of $250-450^{\circ} \mathrm{C}$, with an upper threshold that may be lowered to $\sim 350^{\circ} \mathrm{C}$, as inferred by the lack of antigorite.

Other serpentine species present in the serpentinite sole recorded retrogression during fore-arc cooling and obduction. These serpentinization events occurred under high strain conditions and at lower temperature, from $\sim 250^{\circ} \mathrm{C}$ to $<100^{\circ} \mathrm{C}$. From the oxygen and hydrogen isotope composition of these serpentines, we suggest a meteoric contribution for the late stage serpentinizing fluids. Thus, this study demonstrates that serpentine in ophiolite may record a long history of fluid-rock interactions, from early fluid circulations deep into the forearc mantle to late meteoric fluid percolation at shallow depth during obduction

\section{Acknowledgements}


We thank Claire Bassoulet for her help during LA-ICP-MS measurements at Géosciences Ocean laboratory (Brest, France). We also thank Olivier Rouer (SCMEM, Nancy, France) for his help during electron microprobe analyses. Marie-Camille Caumon (Géoressoures, Nancy, France), and Gilles Montagnac (Laboratoire de Géologie, ENS Lyon, France) are thanked for their contributions during Raman spectroscopy analyses. Benita Putlitz and Thorsten Wennemann (ISTE, University of 662 Lausanne, Switzerland) are acknowledged for their help during the measurement of $\mathrm{O}$ and $\mathrm{H}$ isotopes.

Sampling in New Caledonia was partly funded by the National Centre for Technological Research CNRT "Nickel et son environnement” based in Nouméa, New Caledonia (Project grant: 8PS2013-CNRT.CNRS/SCANDIUM) and Labex Ressources21 (supported by the French National Research Agency through the National Program Investissements d'Avenir, reference ANR-10LABX-21-LABEXRESSOURCES 21). The fieldwork benefited from the help of Koniambo S.A.. Juan Carlos de Obeson, an anonymous reviewer and the editor Othmar Müntener are warmly acknowledged for their detailed and constructive suggestions that helped to improve the manuscript. 
Figure 1: Simplified geological map of New Caledonia, showing the exposures of Paleocene-Eocene terranes, (adapted from Maurizot and Vende-Leclerc, 2009). Pre-obduction situation is modified from Cluzel et al. (2012).

Figure 2: a, b. Slightly $(<20 \%)$ to moderately $(\sim 50 \%)$ serpentinized peridotite, respectively corresponding to the "facies supérieur" (b) and "facies intermediaire" (a) described in Orloff (1968). c. Serpentinite from the base of the ophiolite nappe, just above the serpentinite sole. d, e, f. Serpentinite from the serpentinite sole showing multiple generations of serpentine in the form of veins and fracture infilling. These serpentines include centimeter-scale greenish veins (d) that are crosscut by millimeter-scale veins filled by fibrous serpentine and/or light green to white-colored massive serpentine (e, f).

Figure 3: a. Microphotography (cross-polarized) of the typical mesh texture (S1) observed in serpentinized peridotite and serpentinites from the upper parts of the Peridotite Nappe. Black veins correspond to magnetite (sample MS60). b. Microphotography (cross-polarized) of the serpentinite sole showing the primary mesh texture (S1) crosscut by 4 successive generations of serpentine veins (S2 to S5; sample xx3786). c. Microphotography (cross-polarized) of the serpentinite sole showing the primary mesh texture (S1) crosscut by S3 veins, itself crosscut by fiber-habitus S5 veins and the close association between S5 and S6 serpentines (sample xx3758). d. Schematic representation of (b). mgt: magnetite; chr: chromite.

Figure 4: Raman spectra of the main serpentine species identified in this study.

Figure 5: $\mathrm{Plots}$ of $\mathbf{a}$. $\mathrm{Si}+\mathrm{Al}$ cations vs. $\mathrm{Mg}+\mathrm{Fe}_{\mathrm{T}}$ cations; b. $\mathrm{Mg}$ cations vs. $\mathrm{Fe}_{\mathrm{T}}$ cations; $\mathbf{c}$. $\mathrm{Fe}_{\mathrm{T}}$ cations vs. Al cations; and d. $\mathrm{Mg} \#\left(\mathrm{Mg}^{2+} /\left(\mathrm{Mg}^{2+}+\mathrm{Fe}^{2+}\right)\right)$ vs. $\mathrm{Fe}^{3+} / \mathrm{Fe}_{\mathrm{T}}$ (lower right), showing that serpentine from the sole integrates less $\mathrm{Al}$ and $\mathrm{Fe}_{\mathrm{T}}$ and more oxidized iron than upper serpentines. Compositions of primary minerals are also shown. Ol: olivine; Opx: orthopyroxene; Cpx: clinopyroxene. Atoms per formula units are calculated based on 7 oxygens for serpentine minerals, except for antigorite which is calculated based on 6.823 oxygens. Olivine and pyroxene structural formulas are calculated based on 4 and 6 oxygens, respectively, and then converted to 7 oxygens for comparison with serpentine minerals. Brucite and $\mathrm{Fe}^{3+}$ dioctahedral substitution trends are from Beard and Frost (2017). 
Figure 6: PM-normalized extended trace element patterns of serpentine minerals. a. Lizardite from upper serpentines compared to their magmatic mineral precursors (olivine, orthopyroxene, clinopyroxene). The first serpentine generation (lizardite S1) preserves the initial trace element patterns. b. Trace element patterns of lizardite from the serpentinite sole (S2) compared to lizardite S1. c. Trace element patterns of antigorite (S3) from the serpentinite sole compared to lizardite S2. d. Trace element patterns of chrysotile (S5) and polygonal serpentine (S6) from the serpentinite sole compared to lizardite S2. S1 to S2 transition is marked by an enrichment in fluid-mobile elements (in blue), especially with a pronounced $U$ positive anomaly and an enrichment in LREE except for Ce. S2 to S6 transitions occurred isochemically. Primitive-mantle values are from McDonough and Sun (1995).

Figure 7: Plots of concentrations of selected fluid-mobile elements (B, $\mathrm{Li}, \mathrm{Sb}, \mathrm{Pb}$, and $\mathrm{Sr}$ ), U/Th and $\mathrm{Ce} / \mathrm{Ce}^{*}$ ratios in serpentines from Upper serpentinites and from the serpentinite sole. Primitive and depleted mantle values are from McDonough and Sun (1995) and from Workman and Hart (2005), respectively, except for $\mathrm{B}, \mathrm{Li}$ and $\mathrm{Sb}$ concentrations in the depleted mantle which are from Salters and Stracke (2004).Global subducted sediments (GLOSS II) concentrations are from Plank (2014). Other concentration ranges are from Frisby et al. (2016) and Peters et al. (2017) for abyssal serpentinites; Lafay et al. (2013) and Peters et al. (2017) for serpentines with sedimentary imprints; Ulrich et al. (2010) and Secchiari et al. (2016; 2019) for NC serpentinized peridotites; Ulrich et al. (2019) for laterites. $\mathrm{Ce} / \mathrm{Ce}^{*}=\mathrm{Ce}_{\mathrm{N}} /\left[\left(\mathrm{LaN}_{N}^{*} \operatorname{Pr}_{\mathrm{N}}\right)^{1 / 2}\right]$.

Figure 8: a. $\delta \mathrm{D}$ vs. $\delta^{18} \mathrm{O}$ of NC serpentines. Blue and green fields represent the isotopic compositions of oceanic serpentinites and ophiolite serpentinites, respectively (Wenner and Taylor, 1973; FrühGreen et al., 2001). The black arrow shows the trend formed by samples contaminated by supergene silica ( $\delta^{18} \mathrm{O}>29 \%$; Quesnel et al., 2016). Grey areas indicate the range of mantle compositions in $\delta^{18} \mathrm{O}$ and $\delta \mathrm{D}$, with average values of 5.5\% and -80\% respectively (Deloule et al., 1991; Eiler et al., 2001). b. Calculated $\delta \mathrm{D}$ vs. $\delta^{18} \mathrm{O}$ compositions of serpentinizing fluids (represented as a density field) in equilibrium with $\mathrm{NC}$ serpentines ( 6500 positive results, i.e., consistent with the isotopic compositions of NC serpentines, over 1000000 Monte-Carlo simulations, see the main text for more details about the modeling). The $\mathrm{O}$ and $\mathrm{H}$ compositions of fluids in equilibrium with the altered oceanic crust at $200-400^{\circ} \mathrm{C}$, with subducted sediments (sed. fluids) and with subducted serpentinites (serp. fluids) at $200-350^{\circ} \mathrm{C}$ are calculated according to the modeling approach of Alt and Shanks III (2006). NC meteoric rainwater compositions are from Nicolini et al. (2016). c. and d.Calculated $\delta^{18} \mathrm{O}_{\text {fluid }}$ and $\delta \mathrm{D}_{\text {fluid }}$ vs. temperature of serpentinization. The white cross-hatched area indicates simulations that fall into the red area in (b) ( $40 \%$ of $>6500$ simulations). Colorbar values correspond 
to the number of pixels in one grid cell of a size of $1 \%\left(\delta^{18} \mathrm{O}\right)$ by $10 \%(\delta \mathrm{D})$ in $(\mathrm{b}), 50^{\circ} \mathrm{C}(\mathrm{T})$ by $1 \%$ $\left(\delta^{18} \mathrm{O}\right)$ in $(\mathrm{c})$ and $50^{\circ} \mathrm{C}(\mathrm{T})$ by $10 \%(\delta \mathrm{D})$ in $(\mathrm{d})$.

Figure 9: Plots of a. U/Th vs. U and b. B/Zr vs. B of NC serpentines. Thick solid lines represent the 5
7644 derived fluids (in blue) and with serpentine-derived fluids (in green). Thin dotted lines represent the bulk mixing between the $\mathrm{NC}$ mantle wedge and AOC-derived fluids mixed with various amounts of sediment-derived fluids (in orange) and serpentine-derived fluids (in green). Grey dotted lines correspond to the percentage additions of slab-derived fluids to the mantle wedge. Compositions of the NC mantle wedge and AOC, sediment and serpentine-derived fluids and respective sources are listed in Table 4.

Figure 10: a. A simple model for the serpentinization of the New Caledonia ophiolite. a. Massive hydration of the forearc mantle related to the dehydration of the altered oceanic basement of the subducted plate, leading to the formation of fully serpentinized peridotites (including pyroxenes) at the slab interface, where fluid flows are the most intense, and partially serpentinized peridotites at shallower depths where fluid flows are less expressed. b. Conceptual model of the serpentinite sole formation in response to the percolation of meteoric fluids at the base of the NC ophiolite during its emplacement on the Norfolk continental basement. Note that these meteoric fluids previously interacted with peridotite the top of the ophiolite, forming a thick regolith since the ophiolite emersion at 34 Ma. (modified after Lagabrielle et al., 2013). The legend is the same as in Figure 1. 
Table 1: Representative major element concentrations of primary minerals (olivine, orthopyroxene and clinopyroxene) and serpentines from NC peridotites.

Table 2: Representative trace element concentrations of primary minerals (olivine, orthopyroxene and clinopyroxene) and serpentines from NC peridotites.

Table 3: Oxygen and hydrogen compositions of NC serpentines (US: upper serpentinites; Lhz: lherzolite; Hz: harzburgite; Du: dunite; lz: lizardite; atg: antigorite; ctl: chrysotile; pol: polygonal serpentine; BR: bulk rock).

Table 4: Chemical compositions, mobilities and references used for trace element modeling. 


\section{REFERENCES}

Agard P, Yamato P, Soret M, Prigent C, Guillot S, Plunder A, Dubacq B, Chauvet A, Monié P (2016) Plate interface rheological switches during subduction infancy: Control on slab penetration and metamorphic sole formation. Earth Planet Sci Lett 451:208-220

Agrinier P, Cannat M (1997) Oxygen-isotope constraints on serpentinization processes in ultramafic rocks from the MidAtlantic Ridge $\left(23^{\circ} \mathrm{N}\right)$. Proceedings of Ocean Drilling Program, Scientific Results 153:381-388

Agrinier P, Hékinian R, Bideau D, Javoy M (1995) O and H stable isotope compositions of oceanic crust and upper mantle rocks exposed in the Hess Deep near the Galapagos Triple Junction. Earth Planet Sci Lett 136(3-4):183-196

Aitchison JC, Clarke GL, Meffre S, Cluzel D (1995) Eocene arc-continent collision in New Caledonia and implications for regional southwest Pacific tectonic evolution. Geology 23(2):161

Aizawa Y, Tatsumi Y, Yamada H (1999) Element transport by dehydration of subducted sediments: Implication for arc and ocean island magmatism. Island Arc 8(1):38-46

Alt JC (2003) Stable isotopic composition of upper oceanic crust formed at a fast spreading ridge, ODP Site 801. Geochem Geophys Geosyst 4(5)

Alt JC, Garrido CJ, Shanks III WC, Turchyn A, Padrón-Navarta JA, Sánchez-Vizcaíno VL, Pugnaire MTG, Marchesi C (2012) Recycling of water, carbon, and sulfur during subduction of serpentinites: A stable isotope study of Cerro del Almirez, Spain. Earth and Planetary Science Letters 327-328:1-11

Alt JC, Shanks III WC (2003) Serpentinization of abyssal peridotites from the MARK area, Mid-Atlantic Ridge: sulfur geochemistry and reaction modeling. Geochimica et Cosmochimica Acta 67(4):641-653

Alt JC, Shanks Iii WC (2006) Stable isotope compositions of serpentinite seamounts in the Mariana forearc: Serpentinization processes, fluid sources and sulfur metasomatism. Earth Planet Sci Lett 242(3):272-285

Alt JC, Shanks WC, Bach W, Paulick H, Garrido CJ, Beaudoin G (2007) Hydrothermal alteration and microbial sulfate reduction in peridotite and gabbro exposed by detachment faulting at the Mid-Atlantic Ridge, 15 degrees 20 ' N (ODP Leg 209): A sulfur and oxygen isotope study. Geochem Geophy Geosy 8

Andréani M, Escartin J, Delacour A, Ildefonse B, Godard M, Dyment J, Fallick AE, Fouquet Y (2014) Tectonic structure, lithology, and hydrothermal signature of the Rainbow massif (Mid-Atlantic Ridge $36^{\circ} 14^{\prime} \mathrm{N}$ ). Geochemistry Geophysics Geosystems 15(9):3543-3571

Andréani M, Mével C, Boullier AM, Escartin J (2007) Dynamic control on serpentine crystallization in veins: Constraints on hydration processes in oceanic peridotites. Geochemistry Geophysics Geosystems 8(2):24

Auzende AL, Daniel I, Reynard B, Lemaire C, Guyot Fo (2004) High-pressure behaviour of serpentine minerals: a Raman spectroscopic study. Physics and Chemistry of Minerals 31(5):269-277

Avias J (1967) Overthrust structure of the main ultrabasic new caledonian massives. Tectonophysics 4(4-6):531-541

Bailey EH, Ragnarsdottir KV (1994) Uranium and thorium solubilities in subduction zone fluids. Earth Planet Sci Lett 124(1-4):119-129

Bali E, Audétat A, Keppler H (2010) The mobility of U and Th in subduction zone fluids: an indicator of oxygen fugacity and fluid salinity. Contrib Mineral Petrol 161(4):597-613

Beard JS, Frost BR (2017) The stoichiometric effects of ferric iron substitutions in serpentine from microprobe data. International Geology Review 59(5-6):541-547

Bonatti E, Lawrence JR, Morandi N (1984) Serpentinization of oceanic peridotites: temperature dependence of mineralogy and boron content. Earth Planet Sci Lett 70:88-94

Brenan JM, Shaw HF, Ryerson FJ, Phinney DL (1995) Mineral-aqueous fluid partitioning of trace elements at $900^{\circ} \mathrm{C}$ and 2.0 GPa: Constraints on the trace element chemistry of mantle and deep crustal fluids. Geochim Cosmochim Acta 59(16):3331-3350

Burkhard DJM, O'Neil JR (1988) Contrasting serpentinization processes in the eastern Central Alps. Contrib Mineral Petrol 99(4):498-506 
Burkhard DJM, O'Neil JR (1988) Contrasting serpentinization processes in the eastern Central Alps. Contributions to Mineralogy and Petrology 99(4):498-506

Cannat M, Mevel C, Maia M, Deplus C, Durand C, Gente P, Agrinier P, Belarouchi A, Dubuisson G, Humler E (1995) Thin crust, ultramafic exposures, and rugged faulting patterns at the Mid-Atlantic Ridge $\left(22-24^{\circ} \mathrm{N}\right)$. Geology 23(1):49-52

Cathelineau M, Myagkiy A, Quesnel B, Boiron M-C, Gautier P, Boulvais P, Ulrich M, Truche L, Golfier F, Drouillet M (2016) Multistage crack seal vein and hydrothermal Ni enrichment in serpentinized ultramafic rocks (Koniambo massif, New Caledonia). Miner Deposita 52(7):1-16

Cathelineau M, Quesnel B, Gautier P, Boulvais P, Couteau C, Drouillet M (2015) Nickel dispersion and enrichment at the bottom of the regolith: formation of pimelite target-like ores in rock block joints (Koniambo Ni deposit, New Caledonia). Miner Deposita 51(2):271-282

Chen JH, Edwards RL, Wasserburg GJ (1986) 238U,234U and232Th in seawater. Earth Planet Sci Lett 80(3-4):241-251

Chenin P, Manatschal G, Picazo S, Müntener O, Karner G, Johnson C, Ulrich M (2017) Influence of the architecture of magma-poor hyperextended rifted margins on orogens produced by the closure of narrow versus wide oceans. Geosphere 13(2)

Cluzel D, Aitchison JC, Picard C (2001) Tectonic accretion and underplating of mafic terranes in the Late Eocene intraoceanic fore-arc of New Caledonia (Southwest Pacific): geodynamic implications. Tectonophysics 340(12):23-59

Cluzel D, Boulvais P, Iseppi M, Lahondère D, Lesimple S, Maurizot P, Paquette J-L, Tarantola A, Ulrich M (2019) Slabderived origin of tremolite-antigorite veins in a supra-subduction ophiolite: the Peridotite Nappe (New Caledonia) as a case study. International Journal of Earth Sciences:1-26

Cluzel D, Chiron D, Courme M-D (1998) Discordance de l'Éocène supérieur et événements pré-obduction en NouvelleCalédonie. Comptes Rendus de l'Académie des Sciences - Series IIA - Earth and Planetary Science 327(7):485491

Cluzel D, Jourdan F, Meffre S, Maurizot P, Lesimple S (2012a) The metamorphic sole of New Caledonia ophiolite: $40 \mathrm{Ar} / 39 \mathrm{Ar}$, U-Pb, and geochemical evidence for subduction inception at a spreading ridge. Tectonics 31(3):3016$\mathrm{n} / \mathrm{a}$

Cluzel D, Maurizot P, Collot J (2012b) An outline of the Geology of New Caledonia; from Permian-Mesozoic Southeast Gondwanaland active margin to Cenozoic obduction and supergene evolution. Episodes 35(1):72-86

Cluzel D, Meffre S, Maurizot P, Crawford AJ (2006) Earliest Eocene (53 Ma) convergence in the Southwest Pacific: evidence from pre-obduction dikes in the ophiolite of New Caledonia. Terra Nova 18(6):395-402

Cluzel D, Picard C, Aitchison JC, Laporte C, Meffre S, Parat F (1997) La nappe de Poya (ex-formation des Basaltes) de Nouvelle-Calédonie (Pacifique Sud-Ouest) : un plateau océanique Campanien-Paléocène supérieur obducté à l'Eocène supérieur. Comptes Rendus de l'Academie des Sciences de Paris 324(6):443-451

Cluzel D, Ulrich M, Jourdan F, Meffre S, Paquette J-L, Audet M-A, Secchiari A, Maurizot P (2016) Early Eocene clinoenstatite boninite and boninite-series dikes of the ophiolite of New Caledonia; a witness of slab-derived enrichment of the mantle wedge in a nascent volcanic arc. Lithos 260:429-442

Cluzel D, Whitten M, Meffre S, Aitchison JC, Maurizot P (2018) A Reappraisal of the Poya Terrane (New Caledonia): Accreted Late Cretaceous-Paleocene Marginal Basin Upper Crust, Passive Margin Sediments, and Early Eocene E-MORB Sill Complex. Tectonics 37(1):48-70

Debret B, Andréani M, Godard M, Nicollet C, Schwartz S, Lafay R (2013) Trace element behavior during serpentinization/de-serpentinization of an eclogitized oceanic lithosphere: A LA-ICPMS study of the Lanzo ultramafic massif (Western Alps). Chemical Geology 357:117-133

Delacour A, Früh-Green GL, Frank M, Gutjahr M, Kelley DS (2008) Sr- and Nd-isotope geochemistry of the Atlantis Massif ( $\left.30^{\circ} \mathrm{N}, \mathrm{MAR}\right)$ : Implications for fluid fluxes and lithospheric heterogeneity. Chemical Geology 254(1-2):1935

Deloule E, Albarede F, Sheppard SMF (1991) Hydrogen Isotope Heterogeneities in the Mantle from Ion Probe Analysis of Amphiboles from Ultramafic Rocks. Earth and Planetary Science Letters 105(4):543-553

Dequincey O, Chabaux F, Clauer N, Sigmarsson O, Liewig N, Leprun JC (2002) Chemical mobilizations in laterites: evidence from trace elements and 238U-234U-230Th disequilibria. Geochim Cosmochim Acta 66(7):1197-1210

Deschamps F (2010). Université Joseph Fourier 
Deschamps F, Godard M, Guillot S, Chauvel C, Andréani M, Hattori KH, Wunder B, France L (2012) Behavior of fluidmobile elements in serpentines from abyssal to subduction environments: Examples from Cuba and Dominican Republic. Chemical Geology 312-313:93-117

Deschamps F, Godard M, Guillot S, Hattori KH (2013) Geochemistry of subduction zone serpentinites: A review. Lithos 178:96-127

Deschamps F, Guillot S, Godard M, Andréani M, Hattori KH (2011) Serpentinites act as sponges for fluid-mobile elements in abyssal and subduction zone environments. Terra Nova 23(3):171-178

Deville E, Prinzhofer A (2016) The origin of N2-H2-CH4-rich natural gas seepages in ophiolitic context: A major and noble gases study of fluid seepages in New Caledonia. Chemical Geology 440:139-147

Eiler JM (2001) Oxygen isotope variations of basaltic lavas and upper mantle rocks. Stable Isotope Geochemistry 43:319364

Eiler JM, McInnes B, Valley JW, Graham CM, Stolper EM (1998) Oxygen isotope evidence for slab-derived fluids in the sub-arc mantle. Nature 393(6687):777-781

Eissen J-P, Crawford AJ, Cotten J, Meffre S, Bellon H, Delaune M (1998) Geochemistry and tectonic significance of basalts in the Poya Terrane, New Caledonia. Tectonophysics 284(3-4):203-219

Elderfield H, Greaves MJ (1982) The rare earth elements in seawater. Nature 296(5854):214-219

Evans B, Johannes W, Oterdoom H, Trommsdorff V (1976) Stability of chrystotile and antigorite in the serpentine multisystem. Schweizerische Mineralogische und Petrographische Mitteilungen 56:79-93

Evans BW (2004) The serpentinite multisystem revisited: Chrysotile is metastable. International Geology Review 46(6):479-506

Frisby C, Bizimis M, Mallick S (2016) Seawater-derived rare earth element addition to abyssal peridotites during serpentinization. Lithos 248-251:432-454

Fritsch E, Juillot F, Dublet G, Fonteneau L, Fandeur D, Martin E, Caner L, Auzende AL, Grauby O, Beaufort D (2016) An alternative model for the formation of hydrous $\mathrm{Mg} / \mathrm{Ni}$ layer silicates ('deweylite'/'garnierite') in faulted peridotites of New Caledonia: I. Texture and mineralogy of a paragenetic succession of silicate infillings. European Journal of Mineralogy 28(2):295-311

Frost BR, Evans KA, Swapp SM, Beard JS, Mothersole FE (2013) The process of serpentinization in dunite from New Caledonia. Lithos 178:24-39

Früh-Green G, Plas A, Lécuyer C (1996) Petrologic and stable isotope constraints on hydrothermal alteration and serpentinization of the EPR shallow mantle at Hess Deep(Site 895). Proceedings of the Ocean Drilling Program Scientific Results 147:255-291

Früh-Green G, Scambelluri M, Vallis F (2001) OH isotope ratios of high pressure ultramafic rocks: implications for fluid sources and mobility in the subducted hydrous mantle. Contributions to Mineralogy and Petrology 141(2):145159

Fryer P (1992) A synthesis of Leg 125 drilling of serpentine seamounts on the Mariana and Izu-Bonin forearcs. In, vol Fryer, P., Pearce, J.A., Stokking, L.B., et al., 1992. Proc. ODP, Sci. Results, 125: College Station, TX (Ocean Drilling Program). pp 593-614

Gautier P, Quesnel B, Boulvais P, Cathelineau M (2016) The emplacement of the Peridotite Nappe of New Caledonia and its bearing on the tectonics of obduction. Tectonics 35(12):3070-3094

Gillard M, Tugend J, Müntener O, Manatschal G, Karner G, Autin J, Sauter D, Figueredo PH, Ulrich M (2019) The role of serpentinization and magmatism in the formation of decoupling interfaces at magma-poor rifted margins. Earth Science Reviews 196:102882

Guillot S, Hattori KH, Agard P, Schwartz S, Vidal O (2009) Exhumation processes in oceanic and continental subduction contexts: a review. In: Subduction zone geodynamics, vol. Springer, pp 175-205

Guillot S, Hattori KH, de Sigoyer J (2000) Mantle wedge serpentinization and exhumation of eclogites: insights from eastern Ladakh, northwest Himalaya. Geology 28(3):199

Guillot S, Schwartz S, Reynard B, Agard P, Prigent C (2015) Tectonic significance of serpentinites. Tectonophysics 646:1-19

Hattori KH, Guillot S (2003) Volcanic fronts form as a consequence of serpentinite dehydration in the forearc mantle wedge. Geology 31(6):525-528 
Hattori KH, Guillot S (2007) Geochemical character of serpentinites associated with high- to ultrahigh-pressure metamorphic rocks in the Alps, Cuba, and the Himalayas: Recycling of elements in subduction zones. Geochemistry Geophysics Geosystems 8(9):n/a-n/a

Hoefs J (2009) Stable Isotope Geochemistry. Springer, Berlin

Hyndman RD, Peacock SM (2003) Serpentinization of the forearc mantle. Earth Planet Sci Lett 212(3-4):417-432

Iwamori H (1998) Transportation of H2O and melting in subduction zones. Earth and Planetary Science Letters 160(1):6580

Iyer K, Austrheim H, John T, Jamtveit B (2008) Serpentinization of the oceanic lithosphere and some geochemical consequences: Constraints from the Leka Ophiolite Complex, Norway. Chemical Geology 249(1-2):66-90

Klein F, Bach W, McCollom TM (2013) Compositional controls on hydrogen generation during serpentinization of ultramafic rocks. Lithos 178:55-69

Klein F, Marschall HR, Bowring SA, Humphris SE, Horning G (2017) Mid-ocean ridge serpentinite in the Puerto Rico Trench: From seafloor spreading to subduction. J Petrology 58(9):1729-1754

Kodolanyi J, Pettke T, Spandler C, Kamber BS, Gmeling K (2012) Geochemistry of Ocean Floor and Fore-arc Serpentinites: Constraints on the Ultramafic Input to Subduction Zones. J Petrology 53(2):235-270

Kogiso T, Tatsumi Y, Nakano S (1997) Trace element transport during dehydration processes in the subducted oceanic crust: 1. Experiments and implications for the origin of ocean island basalts. Earth Planet Sci Lett 148(1-2):193205

Kyser TK, O'Hanley DS, Wicks FJ (1999) The origin of fluids associated with serpentinization processes: evidence from stable-isotope compositions. The Canadian Mineralogist 37(1):223-237

Lafay R, Deschamps F, Schwartz S, Guillot S, Godard M, Debret B, Nicollet C (2013) High-pressure serpentinites, a trap-and-release system controlled by metamorphic conditions: Example from the Piedmont zone of the western Alps. Chemical Geology 343:38-54

Lemaire C (2000) Application des spectroscopies vibrationnelles à la détection d'amiante dans les matériaux et à l'étude des serpentines. Université de Paris 7

Longerich HP, Jackson SE, Günther D (1996) Laser ablation inductively coupled plasma mass spectrometric transient signal data acquisition and analyte concentration calculation. Journal of Analytical Atomic Spectrometry 11(9):899-904

Magaritz M, Taylor HP (1974) Oxygen and hydrogen isotope studies of serpentinization in the Troodos ophiolite complex, Cyprus. Earth and Planetary Science Letters 23(1):8-14

McDonough WF, Sun SS (1995) The composition of the Earth. Chemical Geology 120(3-4):223-253

McRae ME (2018) Nickel. In: US Geological Survey, Mineral Commodity Summaries, vol., U.S. Geological Survey, Mineral Commodity Summaries, pp 112-113

Mével C (2003) Serpentinization of abyssal peridotites at mid-ocean ridges. Comptes Rendus Geosciences 335(1011):825-852

Monnin C, Chavagnac V, Boulart C, Ménez B, Gérard M, Gérard E, Pisapia C, Quéméneur M, Erauso G, Postec A, Guentas-Dombrowski L, Payri C, Pelletier B (2014) Fluid chemistry of the low temperature hyperalkaline hydrothermal system of Prony Bay (New Caledonia). Biogeosciences 11(20):5687-5706

Mothersole FE, Evans K, Frost BR (2017) Abyssal and hydrated mantle wedge serpentinised peridotites: a comparison of the $15^{\circ} 20^{\prime} \mathrm{N}$ fracture zone and New Caledonia serpentinites. Contrib Mineral Petrol 172(8):69

Muñoz M, Ulrich M, Cathelineau M, Mathon O (2019) Weathering processes and crystal chemistry of Ni-bearing minerals in saprock horizons of New Caledonia ophiolite. Journal of Geochemical Exploration 198:82-99

Nicolini E, Rogers K, Rakowski D (2016) Baseline geochemical characterisation of a vulnerable tropical karstic aquifer; Lifou, New Caledonia. Biochemical Pharmacology 5:114-130

O'Hanley DS (1996) Serpentinites: records of tectonic and petrological history. Oxford University Press,

Orloff O (1968) Etude geologique et geomorphologique des massifs d'ultrabasites compris entre Houailou et Canala (Nouvelle-Caledonie).

Peacock SM (1990) Fluid Processes in Subduction Zones. Science 248(4):329-337

Peacock SM, Hyndman RD (1999) Hydrous minerals in the mantle wedge and the maximum depth of subduction thrust earthquakes. Geophysical Research Letters 26(16):2517-2520 
Pearce NJG, Perkins WT, Westgate JA, Gorton MP, Jackson SE, Neal CR, Chenery SP (1997) A Compilation of New and Published Major and Trace Element Data for NIST SRM 610 and NIST SRM 612 Glass Reference Materials. Geostandards and Geoanalytical Research 21(1):115-144

Peters D, Bretscher A, John T, Scambelluri M, Pettke T (2017) Fluid-mobile elements in serpentinites: Constraints on serpentinisation environments and element cycling in subduction zones. Chemical Geology 466:654-666

Picazo S, Cannat M, Delacour A, EscartíN J, Rouméjon S, Silantyev S (2012) Deformation associated with the denudation of mantle-derived rocks at the Mid-Atlantic Ridge $13^{\circ}-15^{\circ} \mathrm{N}$ : The role of magmatic injections and hydrothermal alteration. Geochemistry Geophysics Geosystems 13(9):n/a-n/a

Pinto VHG, Manatschal G, Karpoff AM, Ulrich M, Viana AR (2016) Seawater storage and element transfer associated with mantle serpentinization in magma-poor rifted margins: A quantitative approach. Earth and Planetary Science Letters 459:1-11

Pirard C, Hermann J, O'Neill HSC (2013) Petrology and Geochemistry of the Crust-Mantle Boundary in a Nascent Arc, Massif du Sud Ophiolite, New Caledonia, SW Pacific. J Petrology 54(9):1759-1792

Plank T (2014) The chemical composition of subducted sediments. In: Treatise on geochemistry, vol 4. Elsevier, pp 607629

Poli S, Schmidt MW (2002) Petrology of subducted slabs. Annual Review of Earth and Planetary Siences 30(1):207-235

Quesnel B, Boulvais P, Gautier P, Cathelineau M, John CM, Dierick M, Agrinier P, Drouillet M (2016a) Paired stable isotopes $(\mathrm{O}, \mathrm{C})$ and clumped isotope thermometry of magnesite and silica veins in the New Caledonia Peridotite Nappe. Geochim Cosmochim Acta 183:234-249

Quesnel B, Boulvais P, Gautier P, Cathelineau M, Maurizot P, Cluzel D, Ulrich M, Guillot S, Lesimple S, Couteau C (2013) Syn-tectonic, meteoric water-derived carbonation of the New Caledonia peridotite nappe. Geology 41(10):1063-1066

Quesnel B, Gautier P, Cathelineau M, Boulvais P, Couteau C, Drouillet M (2016b) The internal deformation of the Peridotite Nappe of New Caledonia: A structural study of serpentine-bearing faults and shear zones in the Koniambo Massif. Journal of Structural Geology 85:51-67

Reynard B (2013) Serpentine in active subduction zones. Lithos 178:171-185

Ribeiro Da Costa I, Barriga FJAS, Viti C, Mellini M, Wicks FJ (2008) Antigorite in deformed serpentinites from the MidAtlantic Ridge. European Journal of Mineralogy 20:563-572

Rouméjon S, Cannat M, Agrinier P, Godard M, Andréani M (2015) Serpentinization and Fluid Pathways in Tectonically Exhumed Peridotites from the Southwest Indian Ridge (62-65 E). J Petrology 56(4):703-734

Rüpke LH, Morgan JP, Hort M, Connolly JAD (2004) Serpentine and the subduction zone water cycle. Earth Planet Sci Lett 223(1-2):17-34

Saccocia PJ, Seewald JS, Shanks III WC (2009) Oxygen and hydrogen isotope fractionation in serpentine--water and talcwater systems from 250 to $450^{\circ} \mathrm{C}, 50 \mathrm{MPa}$. Geochimica et Cosmochimica Acta 73(22):6789-6804

Sakai H, Tsutsumi M (1978) D-H Fractionation Factors Between Serpentine and Water at $100^{\circ} \mathrm{C}$ to $500^{\circ} \mathrm{C}$ and $2000 \mathrm{Bar}$ Water-Pressure, and D-H Ratios of Natural Serpentines. Earth and Planetary Science Letters 40(2):231-242

Sakai R, Kusakabe M, Noto M, Ishii T (1990) Origin of waters responsible for serpentinization of the Izu-OgasawaraMariana forearc seamounts in view of hydrogen and oxygen isotope ratios. Earth and Planetary Science Letters 100(1-3):291-303

Salters VJM, Longhi JE, Bizimis M (2002) Near mantle solidus trace element partitioning at pressures up to 3.4 GPa. Geochem Geophys Geosystems 3(7):1-23

Salters VJM, Stracke A (2004) Composition of the depleted mantle. Geochem Geophys Geosyst 5(5):n/a-n/a

Sano T, Hasenaka T, Shimaoka A, Yonezawa C, Fukuoka T (2001) Boron contents of Japan Trench sediments and Iwate basaltic lavas, Northeast Japan arc: estimation of sediment-derived fluid contribution in mantle wedge. Earth Planet Sci Lett 186(2):187-198

Savin SM, Lee M (1988) Isotopic studies of phyllosilicates. In: Bailey S (ed) Hydrous Phyllosilicates (exclusive of micas), vol 19. Mineralogical Society of America, pp 189-223

Savov IP, Ryan J, D‘Antonio M, Kelley K, Mattie P (2005) Geochemistry of serpentinized peridotites from the Mariana Forearc Conical Seamount, ODP Leg 125: Implications for the elemental recycling at subduction zones. Geochemistry Geophysics Geosystems 6(4):- 
Scambelluri M, Fiebig J, Malaspina N, Müntener O, Pettke T (2004) Serpentinite subduction: implications for fluid processes and trace-element recycling. International Geology Review:595-613

Schmidt MW, Poli S (1998) Experimentally based water budgets for dehydrating slabs and consequences for arc magma generation. Earth and Planetary Science Letters 163(1):361-379

Schwartz S, Allemand P, Guillot S (2001) Numerical model of the effect of serpentinites on the exhumation of eclogitic rocks: insights from the Monviso ophiolitic massif (Western Alps). Tectonophysics 342(1-2):193-206

Schwarzenbach EM, Caddick MJ, Beard JS, Bodnar RJ (2015) Serpentinization, element transfer, and the progressive development of zoning in veins: evidence from a partially serpentinized harzburgite. Contributions to Mineralogy and Petrology 171(1):1-22

Secchiari A, Montanini A, Bosch D, Macera P, Cluzel D (2016) Melt extraction and enrichment processes in the New Caledonia lherzolites: Evidence from geochemical and $\mathrm{Sr}-\mathrm{Nd}$ isotope data. Lithos 260:28-43

Secchiari A, Montanini A, Bosch D, Macera P, Cluzel D (2019) Sr, Nd, Pb and trace element systematics of the New Caledonia harzburgites: tracking source depletion and contamination processes in a SSZ setting. Geoscience Frontiers

Sharp Z (1992) In situ laser microprobe techniques for stable isotope analysis. Chemical Geology 101:3-19

Sharp Z, Atudorei V, Durakiewicz T (2001) A rapid method for determination of hydrogen and oxygen isotope ratios from water and hydrous minerals. Chemical Geology 178(1-4):197-210

Sheppard SMF, Nielsen RL, Taylor HP (1969) Oxygen and hydrogen isotope ratios of clay minerals from porphyry copper deposits. Economic Geology 64(7):755-777

Staudigel H, Hart SR, Richardson SH (1981) Alteration of the oceanic crust: Processes and timing. Earth and Planetary Science Letters 52(2):311-327

Stern RJ (2002) Subduction zones. Reviews of Geophysics 40(4):1012

Tenthorey E, Hermann J (2004) Composition of fluids during serpentinite breakdown in subduction zones: Evidence for limited boron mobility. Geology 32(1):865

Thakurta J, Ripley EM, Li C (2009) Oxygen isotopic variability associated with multiple stages of serpentinization, Duke Island Complex, southeastern Alaska. Geochimica et Cosmochimica Acta 73(20):6298-6312

Ulmer P, Trommsdorff V (1995) Serpentine Stability to Mantle Depths and Subduction-Related Magmatism. Science 268(5212):858-861

Ulmer P, Trommsdorff V (1999) Phase relations of hydrous mantle subducting to $300 \mathrm{~km}$. Geochemical Society Special Publication 6:259-281

Ulrich M, Cathelineau M, Muñoz M, Boiron M-C, Teitler Y, Karpoff AM (2019) The relative distribution of critical (Sc, REE) and transition metals (Ni, Co, Cr, Mn, V) in some Ni-laterite deposits of New Caledonia. Journal of Geochemical Exploration 197:93-113

Ulrich M, Muñoz M, Guillot S, Cathelineau M, Picard C, Quesnel B, Boulvais P, Couteau C (2014) Dissolutionprecipitation processes governing the carbonation and silicification of the serpentinite sole of the New Caledonia ophiolite. Contributions to Mineralogy and Petrology 167(1):952-919

Ulrich M, Picard C, Guillot S, Chauvel C, Cluzel D, Meffre S (2010) Multiple melting stages and refertilization as indicators for ridge to subduction formation: The New Caledonia ophiolite. Lithos 115(1):223-236

Wenner D, Taylor H (1971) Temperatures of serpentinization of ultramafic rocks based on O 18/O 16 fractionation between coexisting serpentine and magnetite. Contributions to Mineralogy and Petrology 32(3):165-185

Wenner DB, Taylor HP (1973) Oxygen and hydrogen isotope studies of the serpentinization of ultramafic rocks in oceanic environments and continental ophiolite complexes. American Journal of Science 273(3):207

Whattam SA, Malpas J, Ali JR, Smith IEM (2008) New SW Pacific tectonic model: Cyclical intraoceanic magmatic arc construction and near-coeval emplacement along the Australia-Pacific margin in the Cenozoic. Geochemistry Geophysics Geosystems 9(3):n/a-n/a

Workman RK, Hart SR (2005) Major and trace element composition of the depleted MORB mantle (DMM). Earth Planet Sci Lett 231(1-2):53-72

Wunder B, Wirth R, Gottschalk M (2001) Antigorite: Pressure and temperature dependence of polysomatism and water content. European Journal of Mineralogy 13(3):485

Zheng Y (1993) Calculation of oxygen-Isotope Fractionation in Hydroxyl-Bearing Silicates. Earth and Planetary Science Letters 120:247-263 


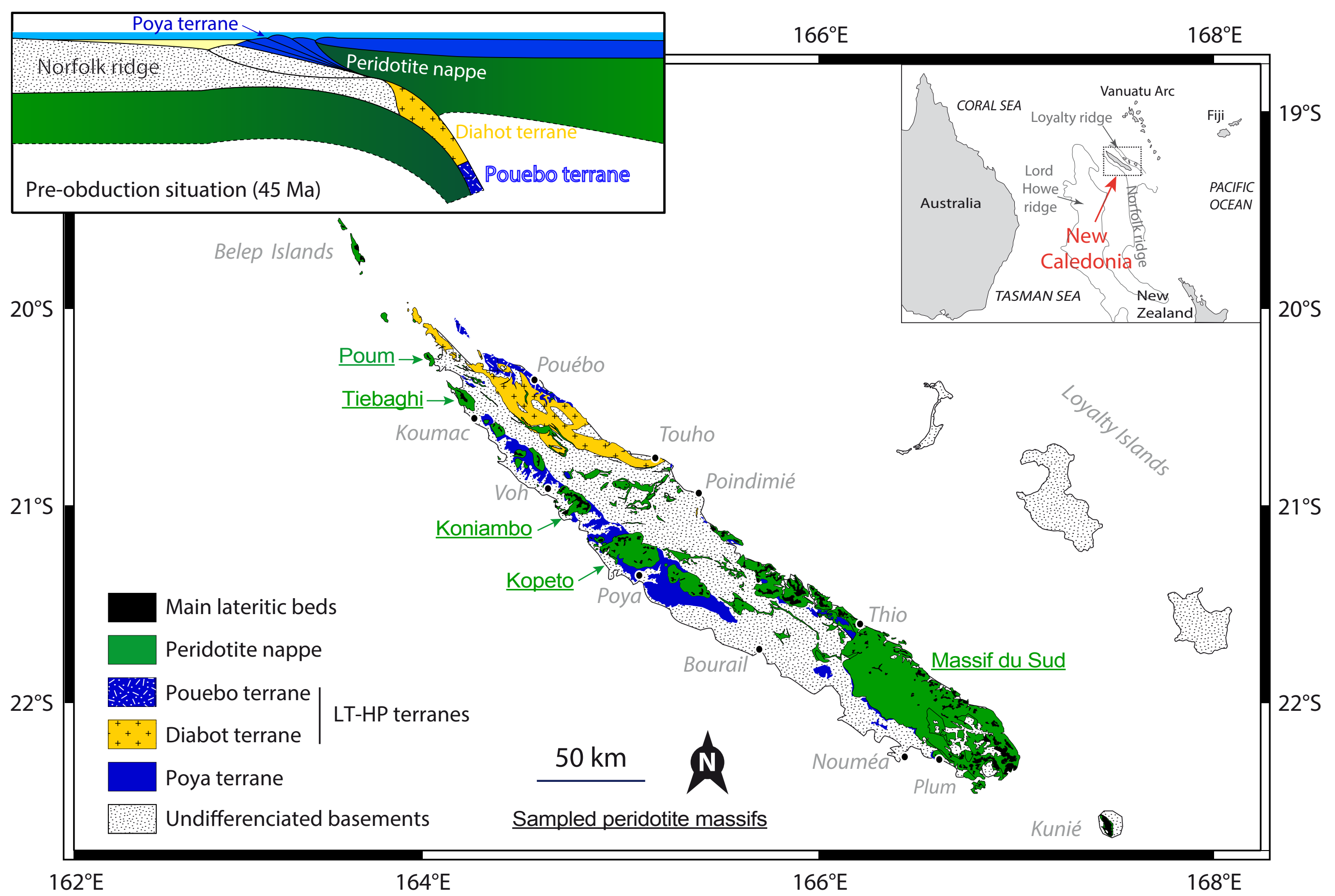




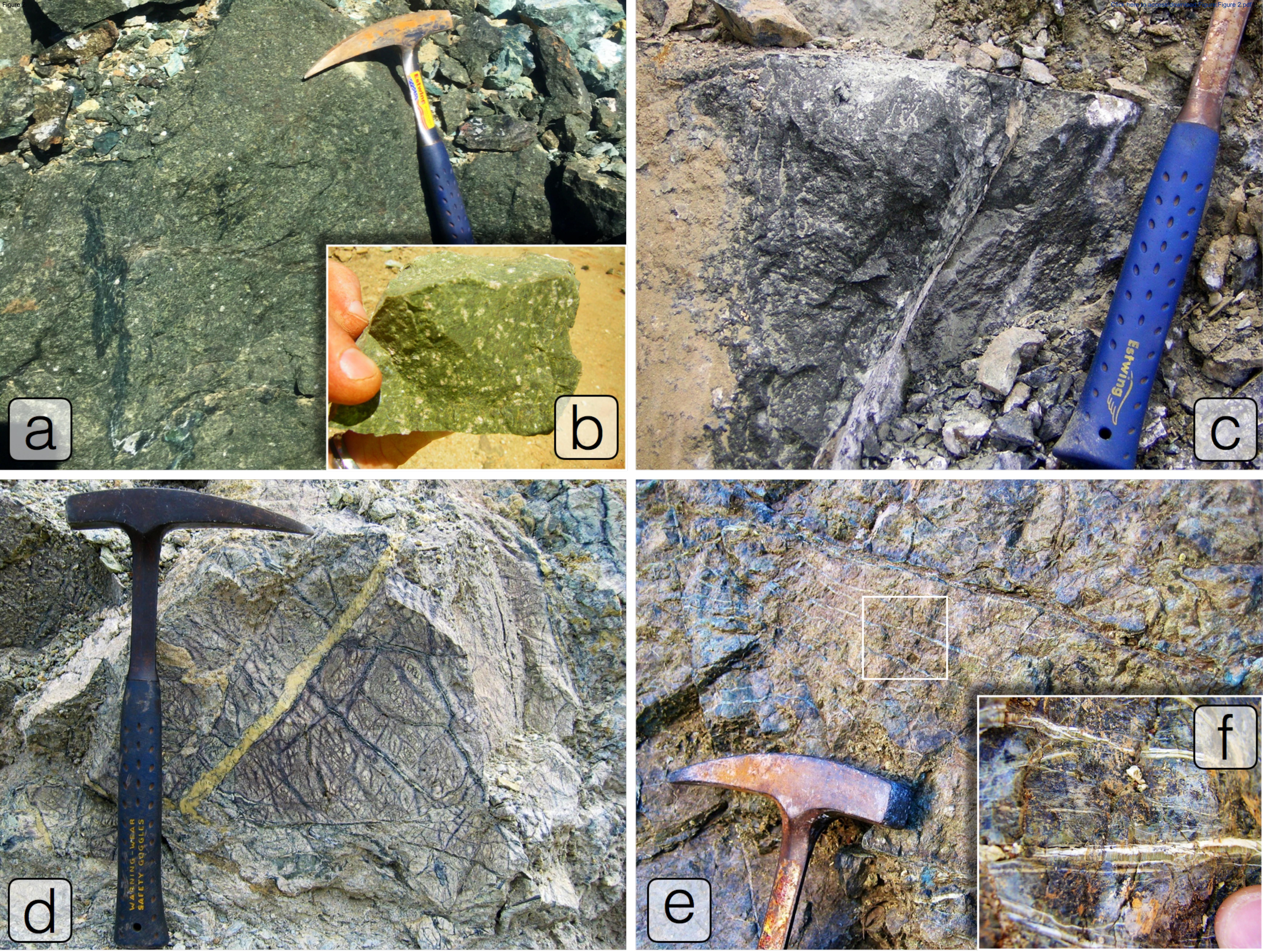




\section{S1}

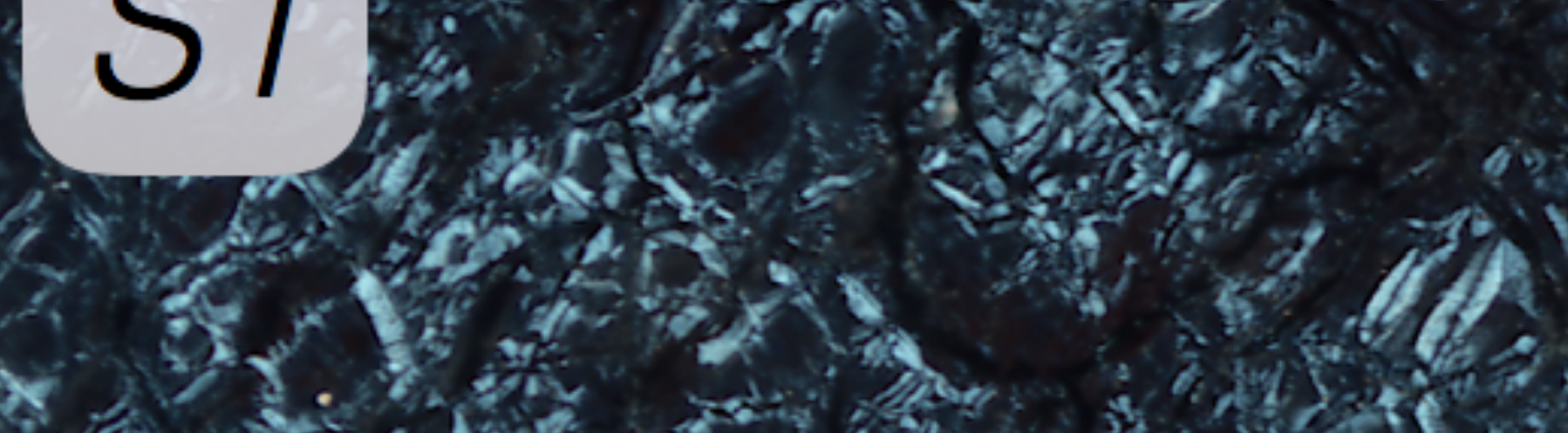

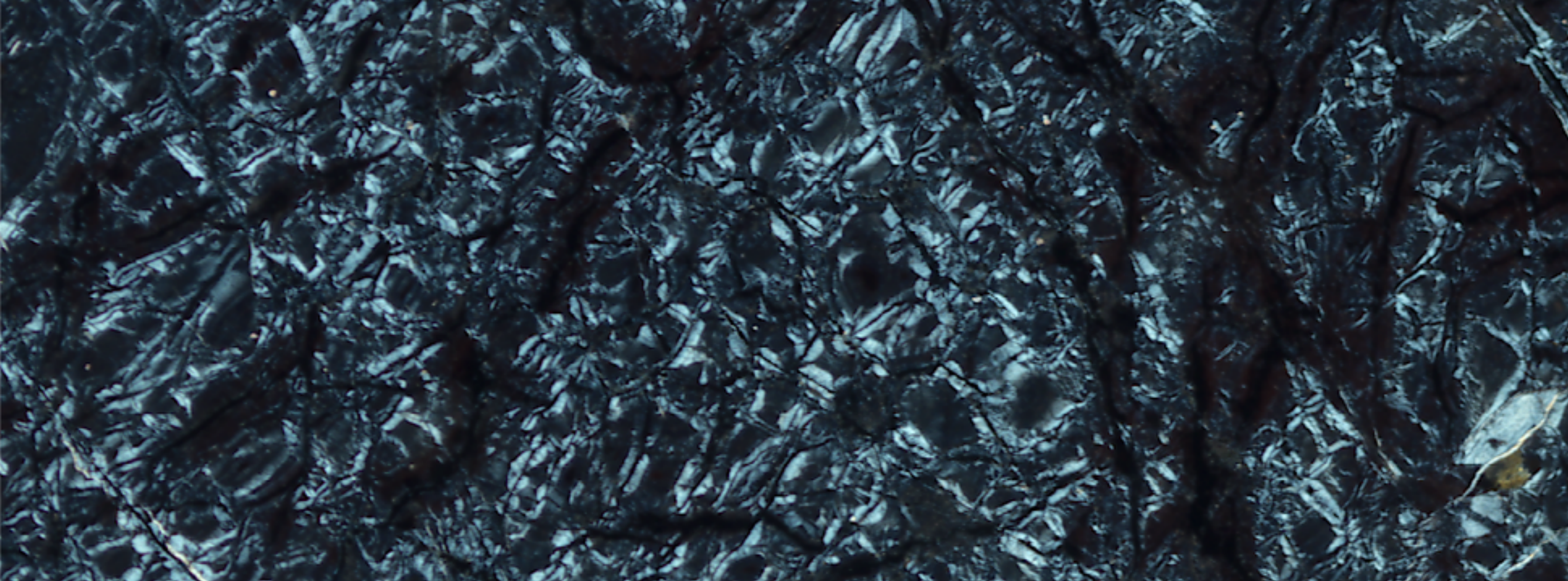
a 7. $600 \mathrm{~mm}$ a

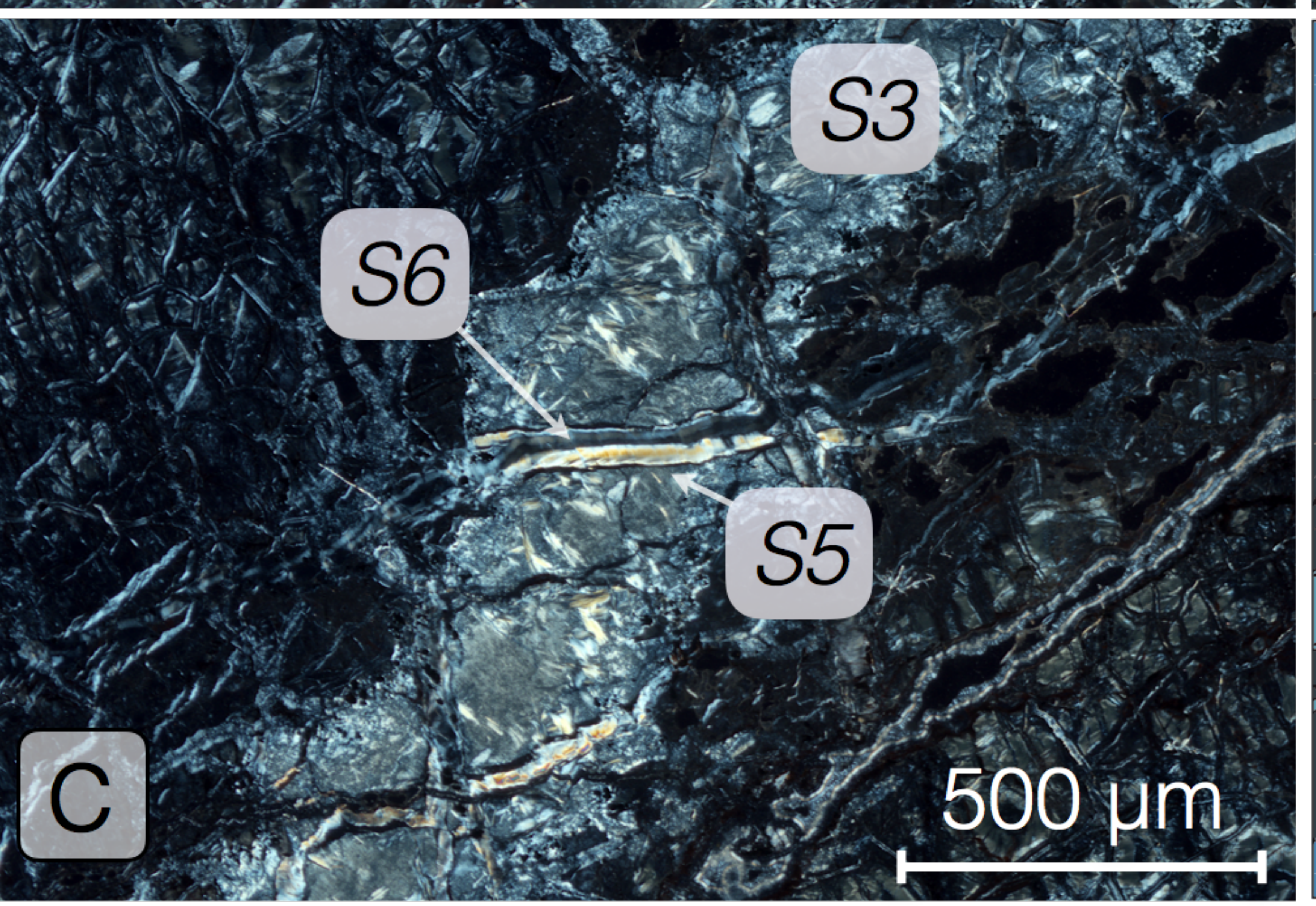

$2 \mathrm{~mm}-1 \mathrm{~b}$

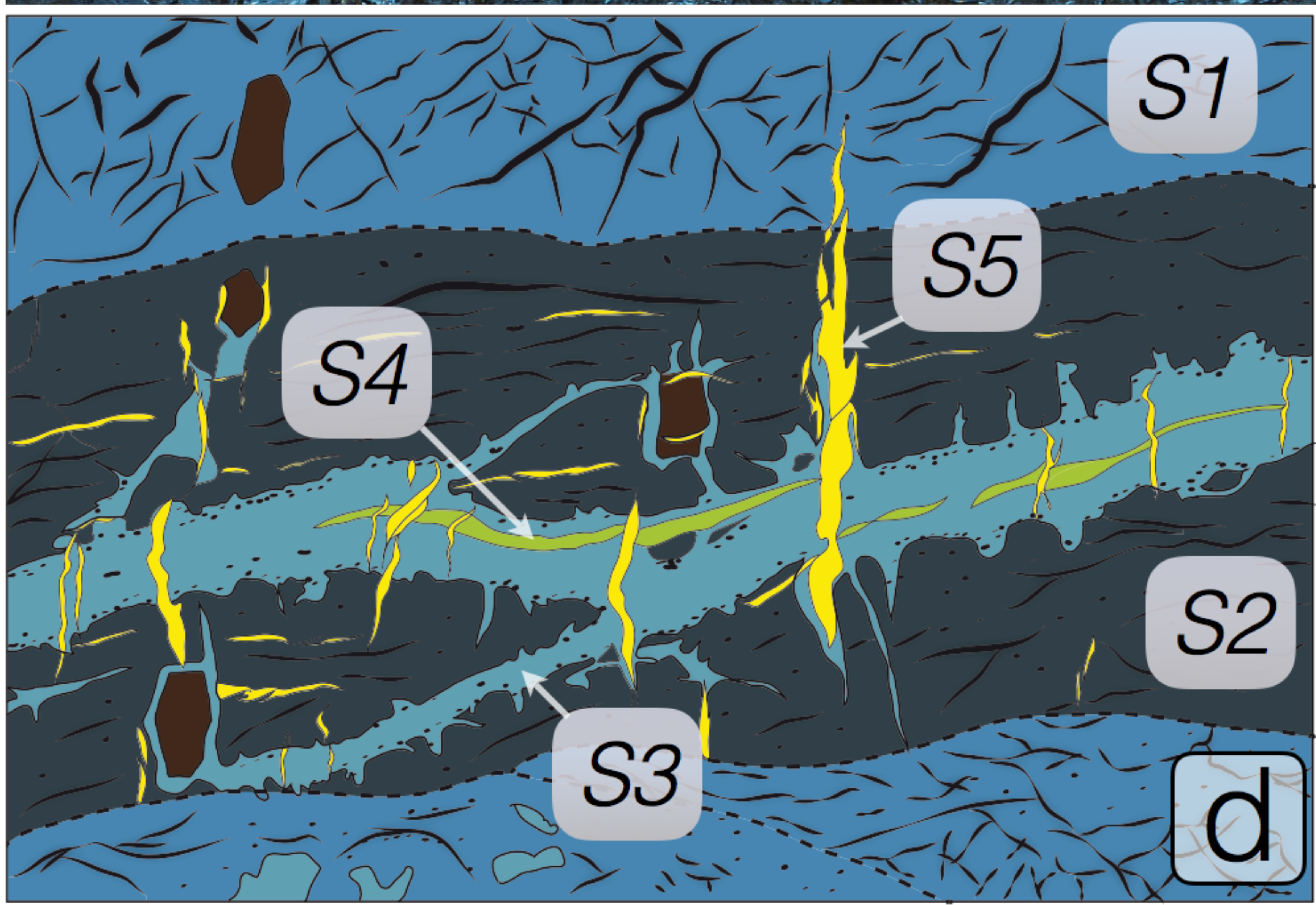



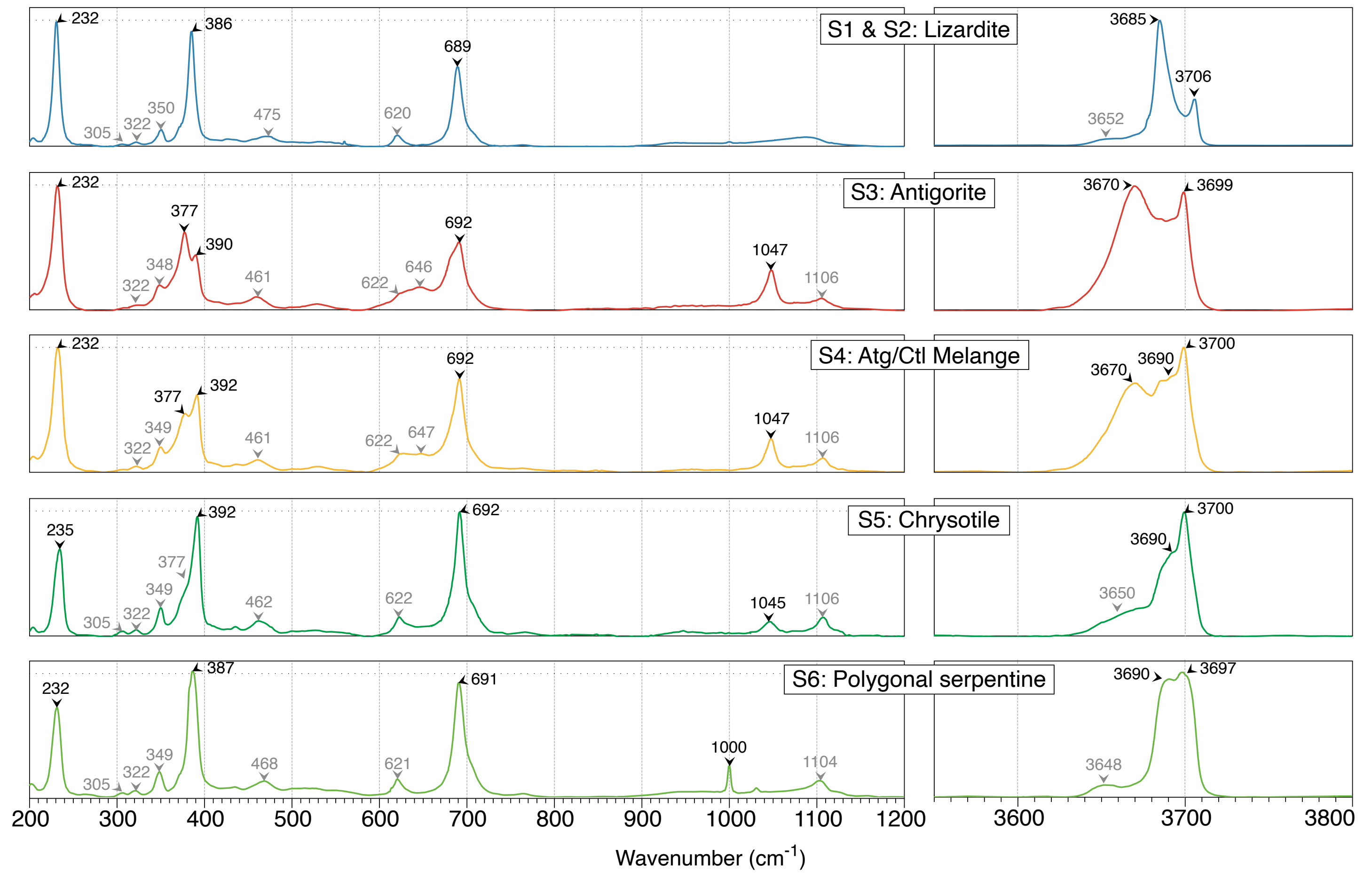
Figure 5

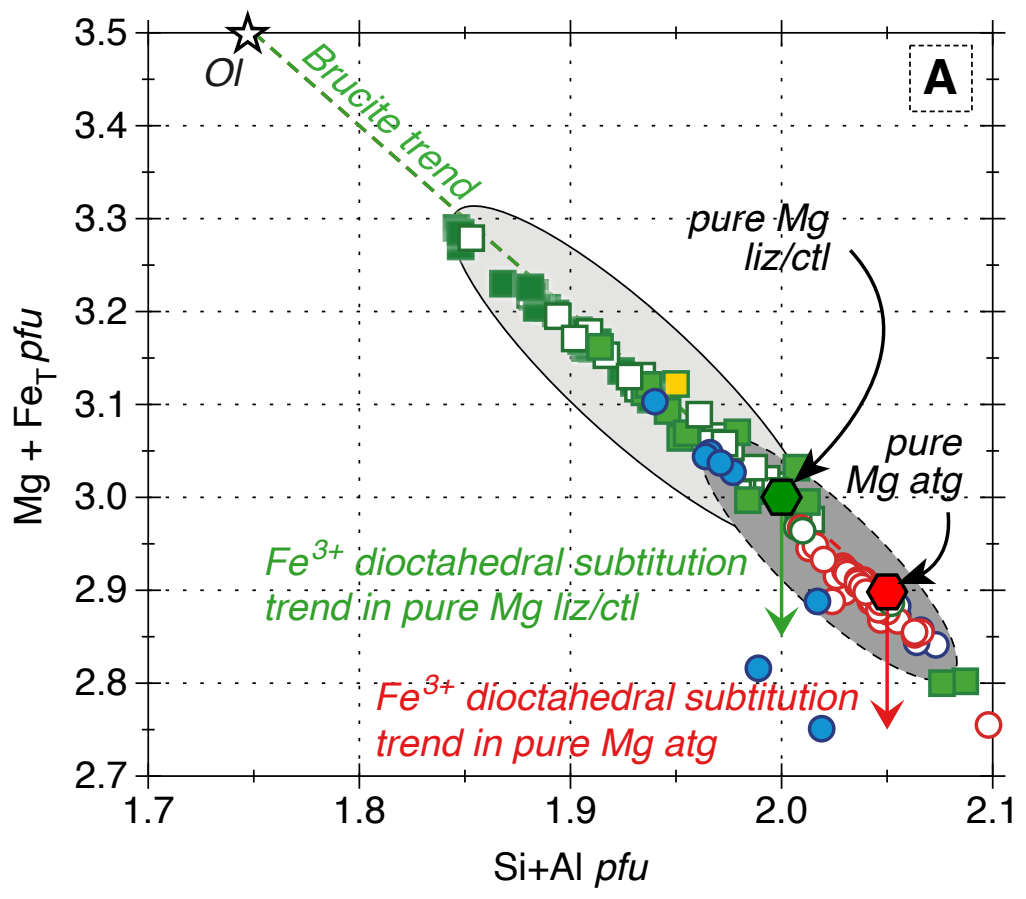

Click here to access/download;Figure;Figure 5.pdf $\underline{\underline{*}}$
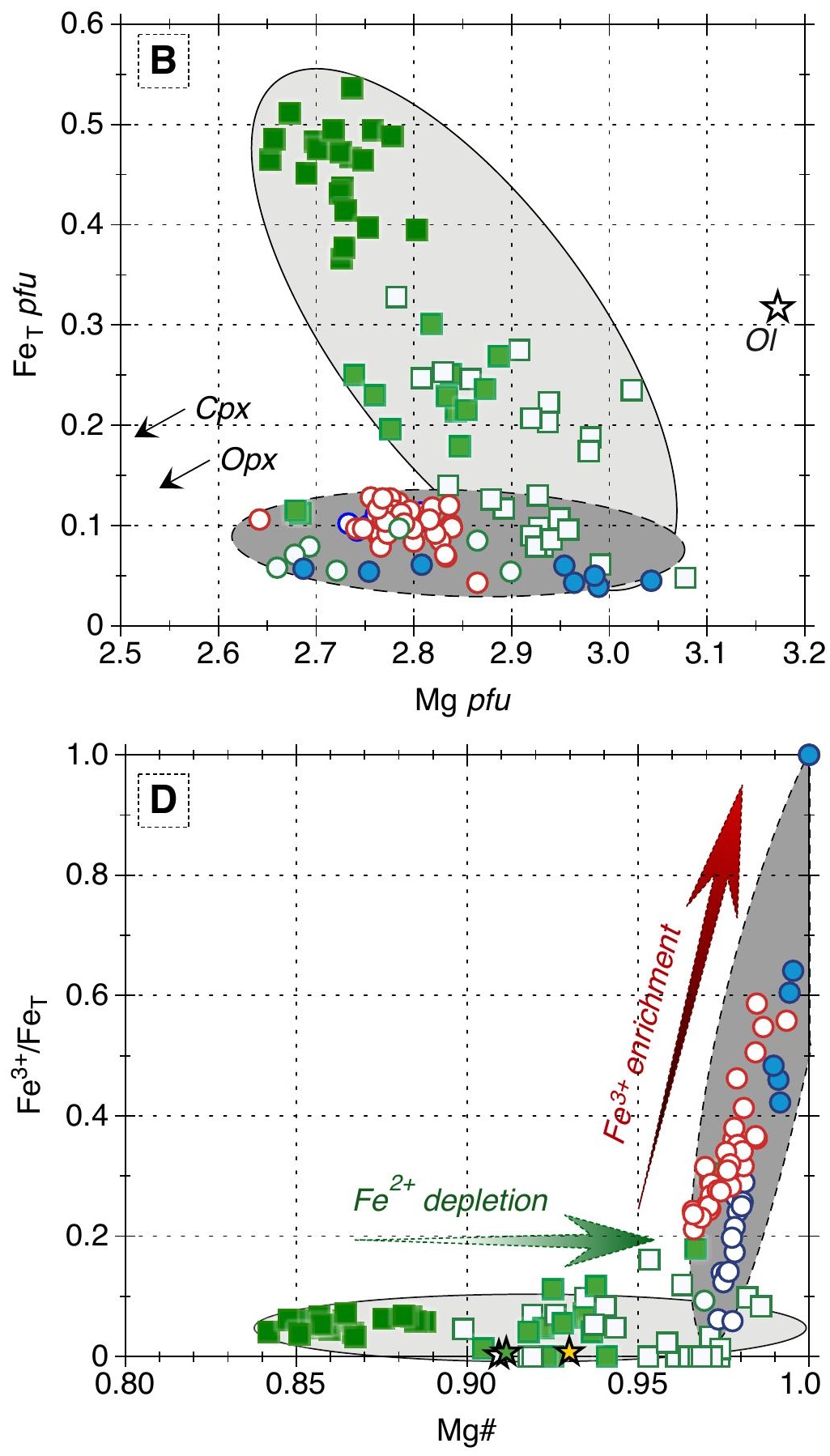

\section{Upper Serpentines}

$\square$ Lizardite (after olivine)

$\square$ Lizardite (after orthopyroxene)

$\square$ Lizardite (after clinopyroxene)

Lizardite (mesh)

\section{Serpentinite sole}

○ Lizardite

○ Antigorite

O Chrysotile

- Polygonal
Primary minerals

㶦 Olivine

支 Orthopyroxene

厺 Clinopyroxene

\section{Fields}

Upper part of the massifs

Serpentinite sole 

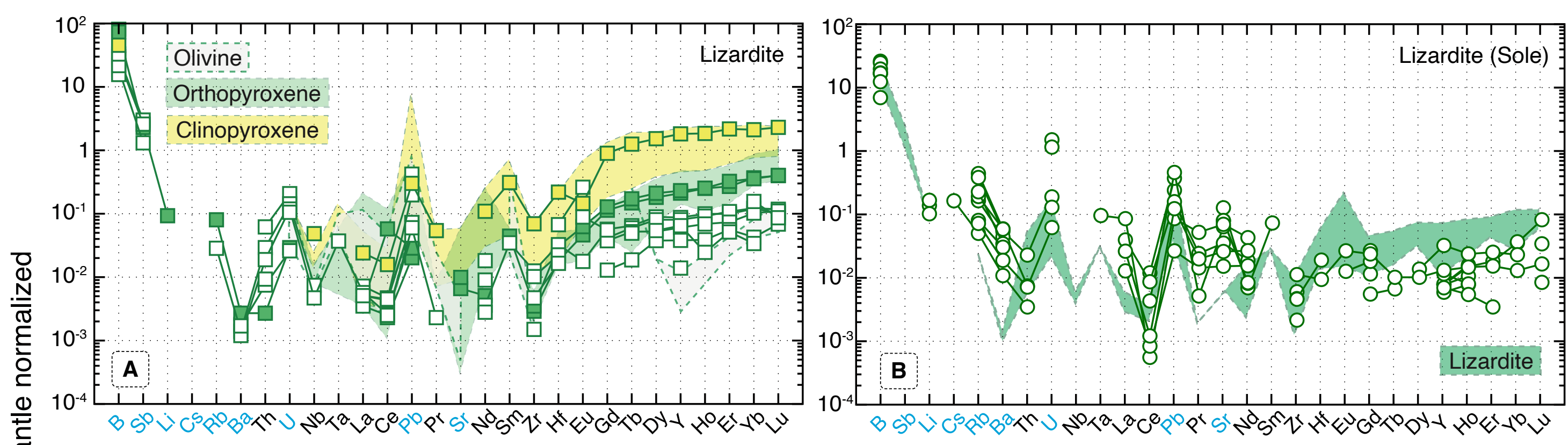

हू
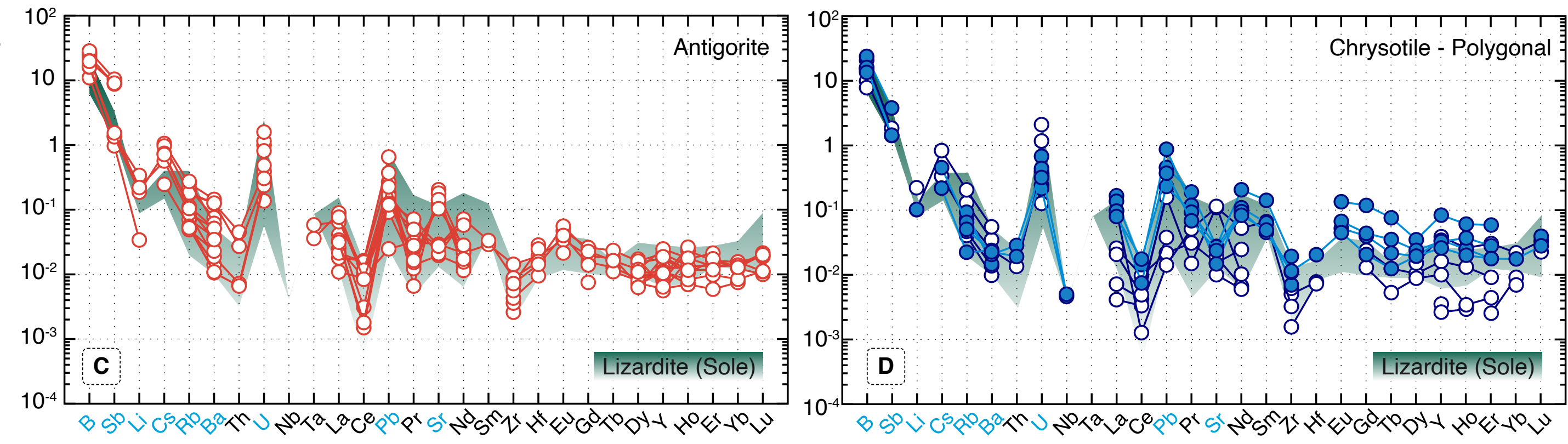

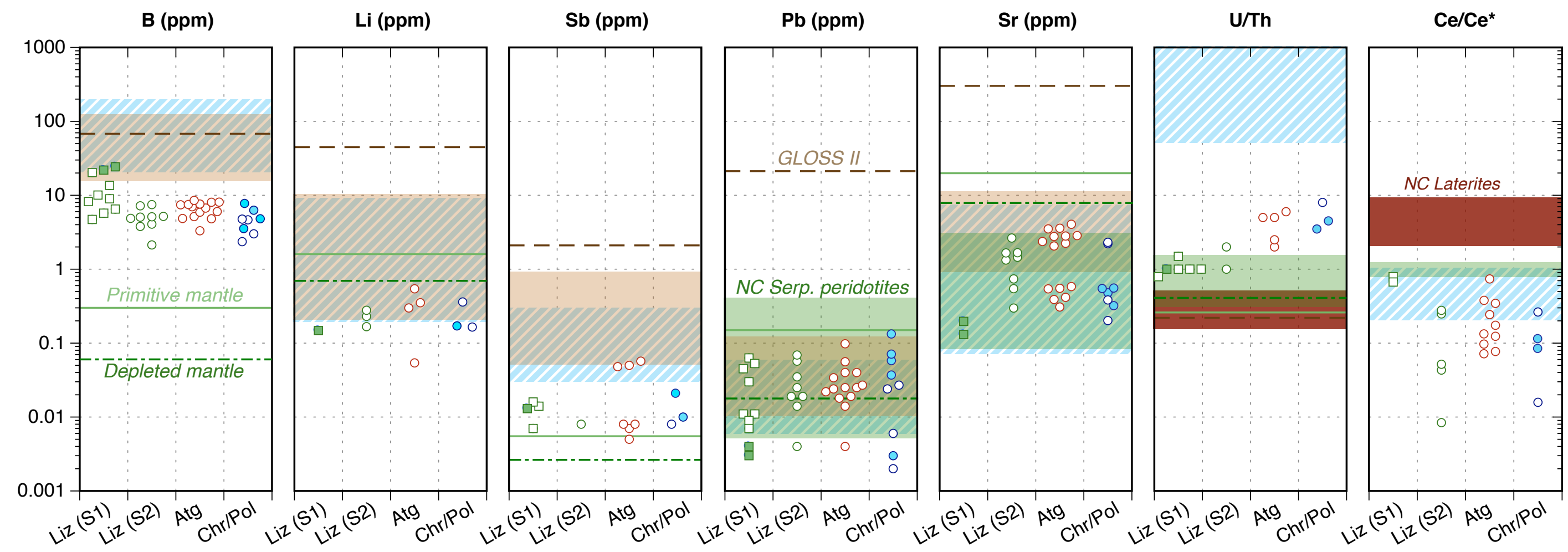

\begin{tabular}{r|l} 
Upper & $\square$ Lizardite (S1) \\
serpentines & $\square$ Lizardite (after opx)
\end{tabular}

\section{Serpentinite} sole
Literature references

O Chrysotile (S5)

O Polygonal serpentine (S6)

Abyssal serpentinites

Serpentines with sediment contribution

NC serpentinized peridotites

NC laterites 

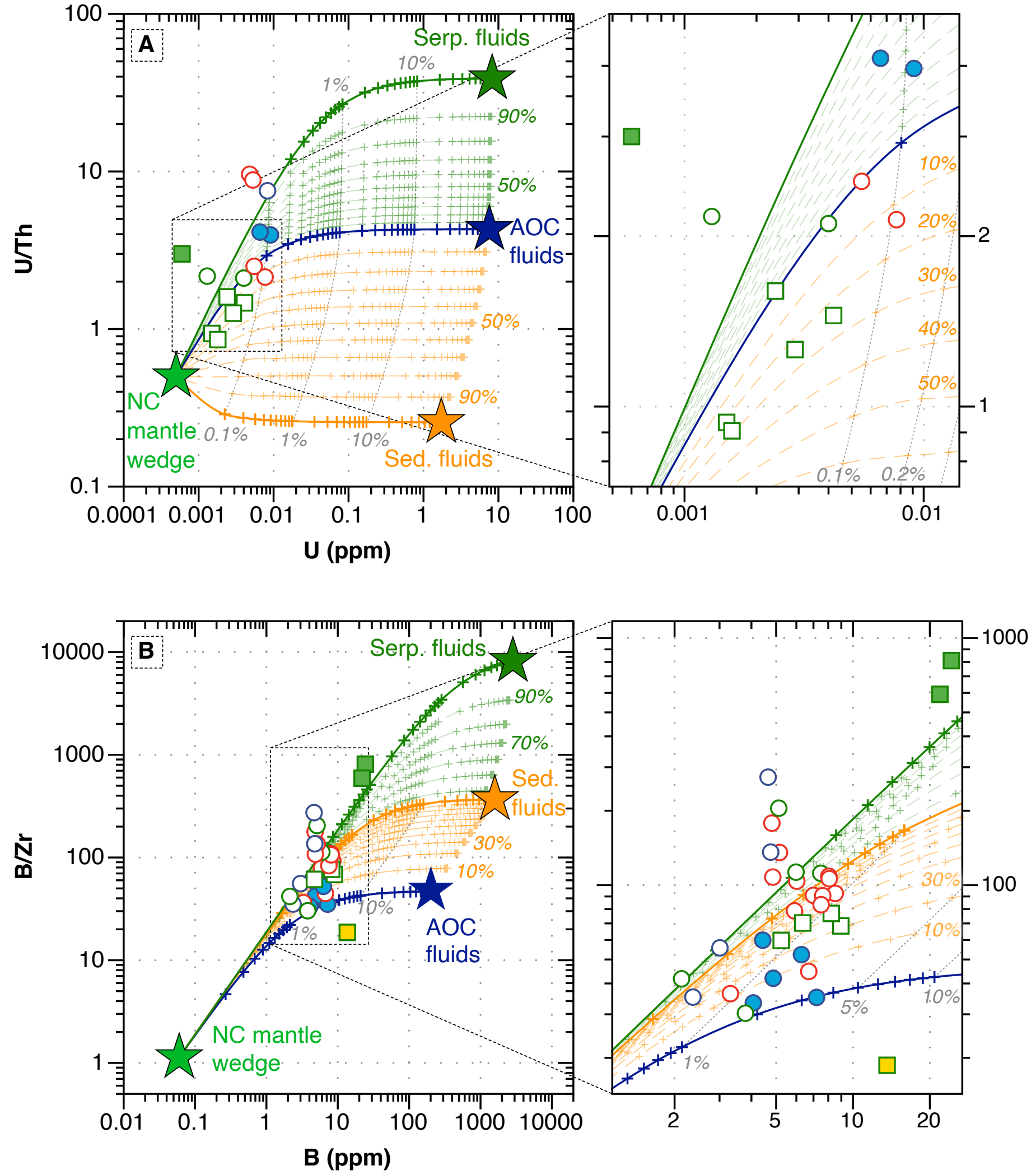


\begin{tabular}{|c|c|c|c|c|c|c|c|c|c|c|c|c|c|}
\hline \multirow{2}{*}{$\begin{array}{l}\text { Structural position } \\
\text { Sample id }\end{array}$} & \multicolumn{12}{|c|}{ Upper part of the ophiolite } & \multirow{5}{*}{$\begin{array}{r}\text { xx3786A-7 } \\
\text { Lizarc } \\
\text { Clast and } \\
\text { matr }\end{array}$} \\
\hline & \multirow{3}{*}{\multicolumn{2}{|c|}{$\begin{array}{c}\text { MS60-1 Ti6-3 } \\
\text { Lizardite } \\
\text { Mesh core }\end{array}$}} & \multirow{3}{*}{\multicolumn{2}{|c|}{$\begin{array}{c}\text { Ti50A-07-6 Ti50A-07-9 } \\
\text { Lizardite } \\
\text { Mesh rim }\end{array}$}} & \multirow{4}{*}{$\begin{array}{c}\text { Ti6-1 } \\
\text { Lizardite } \\
\text { Bastite } \\
\text { Opx }\end{array}$} & \multirow{4}{*}{\begin{tabular}{|c} 
Ti50A-07-3 \\
Lizardite \\
Bastite \\
Cpx
\end{tabular}} & \multirow{2}{*}{\multicolumn{2}{|c|}{$\begin{array}{c}\text { Ti50-2 Ti48 } \\
\text { Olivine }\end{array}$}} & \multirow{2}{*}{\multicolumn{2}{|c|}{$\begin{array}{l}\text { Poum } 17 \text { Ti-48 } \\
\text { Orthopyroxene }\end{array}$}} & \multirow{2}{*}{\multicolumn{2}{|c|}{$\begin{array}{c}\text { TI48-06 Poum-13 } \\
\text { Clinopyroxene }\end{array}$}} & \\
\hline Type & & & & & & & & & & & & & \\
\hline Texture & & & & & & & & & & & & & \\
\hline Primary minerals & Olivir & & Olivi & & & & & & & & & & \\
\hline $\mathrm{SiO}_{2}$ & 40.0 & 41.7 & 38.9 & 38.5 & 42.4 & 39.4 & 41.0 & 40.8 & 55.2 & 55.1 & 51.9 & 51.7 & 43.2 \\
\hline $\mathrm{TiO}_{2}$ & - & & - & 0.01 & 0.07 & 0.04 & - & & 0.09 & 0.11 & 0.30 & 0.27 & 0.04 \\
\hline $\mathrm{Al}_{2} \mathrm{O}_{3}$ & - & 0.57 & 0.01 & & 2.07 & 1.15 & - & & 4.20 & 3.56 & 4.77 & 4.26 & 0.04 \\
\hline $\mathrm{FeO}$ & 5.58 & 2.75 & 10.97 & 11.41 & 2.86 & 5.88 & 8.75 & 8.83 & 6.01 & 5.88 & 2.44 & 2.07 & 2.21 \\
\hline MnO & 0.02 & & 0.19 & 0.04 & 0.15 & 0.18 & 0.16 & 0.14 & 0.16 & 0.15 & 0.10 & 0.12 & 0.08 \\
\hline MgO & 41.3 & 42.4 & 36.7 & 37.5 & 38.7 & 40.3 & 50.0 & 49.8 & 33.5 & 33.1 & 16.3 & 16.3 & 41.4 \\
\hline $\mathrm{CaO}$ & - & & - & & 0.11 & & 0.04 & 0.02 & 0.47 & 1.06 & 23.11 & 23.01 & - \\
\hline $\mathrm{Na}_{2} \mathrm{O}$ & 0.01 & 0.02 & - & & 0.03 & & - & & 0.01 & & 0.29 & 0.38 & - \\
\hline $\mathrm{K}_{2} \mathrm{O}$ & - & & - & & 0.01 & & - & & - & & - & & 0.02 \\
\hline $\mathrm{Cr}_{2} \mathrm{O}_{3}$ & - & & - & -1 & 0.95 & - & 0.01 & 0.01 & 0.66 & 0.88 & 1.01 & 1.11 & - \\
\hline NiO & 0.38 & 0.11 & 0.49 & 0.47 & 0.15 & 0.40 & 0.41 & 0.38 & 0.10 & 0.10 & 0.05 & 0.05 & 0.48 \\
\hline Total & 87.3 & 87.5 & 87.3 & 87.9 & 87.5 & 87.3 & 100.3 & 99.9 & 100.4 & 99.9 & 100.2 & 99.3 & 87.4 \\
\hline Number of oxygen & 7 & & 7 & & 7 & 7 & 4 & & 6 & & & & 7 \\
\hline p.f.u. & & & & & & & & & & & & & \\
\hline Si & 1.92 & 1.95 & 1.91 & 1.88 & 1.97 & 1.86 & 1.00 & 1.00 & 1.90 & 1.91 & 1.88 & 1.89 & 2.00 \\
\hline $\mathrm{Ti}$ & - & & & & 0.002 & & - & & 0.002 & 0.003 & 0.008 & 0.007 & 0.001 \\
\hline Al & 0.018 & 0.031 & 0.001 & & 0.114 & 0.064 & - & & 0.170 & 0.146 & 0.203 & 0.183 & 0.002 \\
\hline $\mathrm{Fe}^{3+}$ & - & & 0.027 & 0.021 & 0.020 & & - & & - & & - & & 0.023 \\
\hline $\mathrm{Fe}^{2+}$ & 0.212 & 0.107 & 0.424 & 0.446 & 0.092 & 0.313 & 0.178 & 0.181 & 0.173 & 0.170 & 0.074 & 0.063 & 0.062 \\
\hline Mn & 0.002 & & 0.008 & 0.002 & 0.006 & 0.007 & - & & 0.005 & 0.005 & 0.003 & 0.004 & 0.003 \\
\hline Mg & 2.90 & 2.95 & 2.69 & 2.73 & 2.68 & 2.84 & 1.81 & 1.81 & 1.72 & 1.71 & 0.88 & 0.89 & 2.86 \\
\hline $\mathrm{Ca}$ & - & & - & & 0.006 & & $<0.001$ & $<0.001$ & 0.017 & 0.039 & 0.897 & 0.900 & - \\
\hline $\mathrm{Na}$ & 0.002 & 0.002 & - & & 0.002 & & - & & $<0.001$ & & 0.020 & 0.027 & - \\
\hline K & - & & - & & 0.001 & & - & & - & & - & & 0.001 \\
\hline $\mathrm{Cr}$ & - & & - & & 0.035 & - & $<0.001$ & $<0.001$ & 0.018 & 0.024 & 0.029 & 0.032 & - \\
\hline $\mathbf{N i}$ & 0.008 & 0.004 & 0.019 & 0.018 & 0.006 & 0.015 & 0.008 & 0.007 & 0.003 & 0.003 & 0.001 & 0.001 & 0.018 \\
\hline Mg\# & 0.93 & 0.96 & 0.86 & 0.86 & 0.97 & 0.90 & 0.91 & 0.91 & 0.91 & 0.91 & 0.92 & 0.93 & 0.98 \\
\hline $\mathrm{Fe}^{3+} /\left(\mathrm{Fe}^{2+}+\mathrm{Fe}^{3+}\right)$ & - & & 0.06 & 0.04 & 0.18 & & - & & - & & - & & 0.27 \\
\hline
\end{tabular}




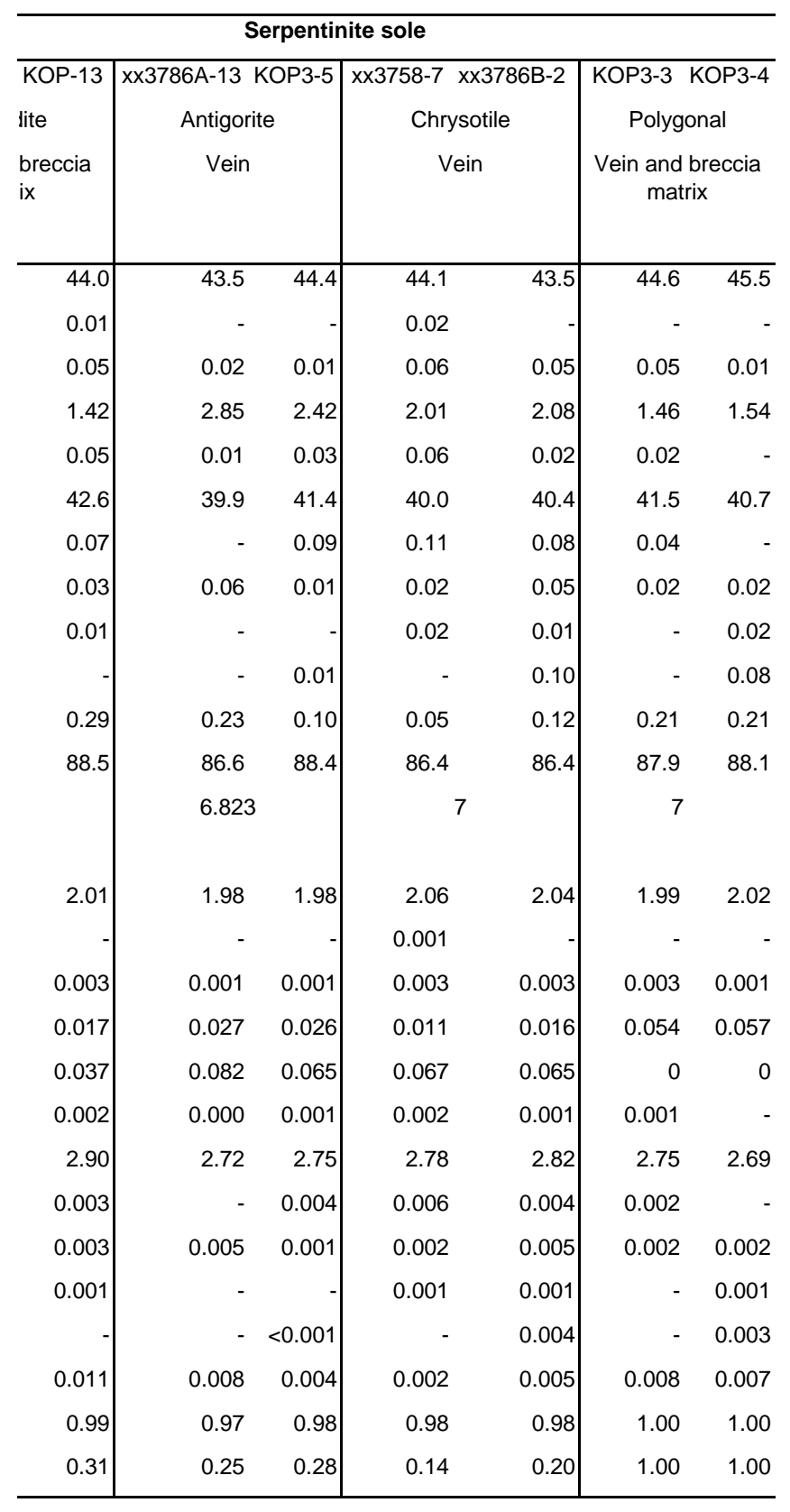




\begin{tabular}{|c|c|c|c|c|c|c|c|c|c|c|c|c|}
\hline \multirow{3}{*}{$\begin{array}{l}\text { Structural position } \\
\text { Type } \\
\text { Texture } \\
\text { Primary minerals }\end{array}$} & \multicolumn{10}{|c|}{ Upper serpentinite } & & \\
\hline & \multirow{2}{*}{\multicolumn{2}{|c|}{$\begin{array}{l}\text { Lizardite } \\
\text { Mesh core } \\
\text { Olivine }\end{array}$}} & \multirow{3}{*}{\begin{tabular}{|c|} 
Lizardite \\
Bastite \\
Opx \\
Ti-6
\end{tabular}} & \multirow{3}{*}{$\begin{array}{c}\text { Lizardite } \\
\text { Bastite } \\
\text { Cpx } \\
\text { Ti-50 }\end{array}$} & \multicolumn{2}{|c|}{ Olivine } & \multicolumn{2}{|c|}{ Orthopyroxene } & \multicolumn{2}{|c|}{ Clinopyroxene } & \multirow{2}{*}{\multicolumn{2}{|c|}{$\begin{array}{l}\text { Lizardite } \\
\text { Clast and breccie }\end{array}$}} \\
\hline & & & & & & & & & & & & \\
\hline & Ti-6 & Ti 50 & & & TI-50 & Poum-13 & $\mathrm{TI}-48$ & Poum-11 & Ti 50 & Poum-11 & $x x-3786 a$ & $\mathrm{Ti}-47$ \\
\hline$\overline{\mathrm{Li}}$ & $<0.071$ & $<0.561$ & $<0.088$ & $<0.684$ & n.d. & n.d. & n.d. & n.d. & n.d. & n.d. & $<0.088$ & $<0.215$ \\
\hline B & 5.72 & 9.89 & 24.3 & 13.6 & n.d. & n.d. & n.d. & n.d. & n.d. & n.d. & 3.79 & 5.98 \\
\hline $\mathrm{Ti}$ & 60.1 & 60.3 & 159 & 2163 & 14.0 & 14.0 & 646 & 239 & 1766 & 542 & $<1.80$ & b.d.l. \\
\hline $\mathrm{Mn}$ & 166.712 & 847 & 635 & 1460 & 1057 & 1004 & 1090 & 1096 & 747 & 638 & 80.8 & 116 \\
\hline Co & 31.8628 & 81.1 & 27.3 & 67.4 & 147 & 146 & 63.0 & 59.0 & 28.0 & 24.0 & 18.2 & 45.3 \\
\hline $\mathbf{N i}$ & 783 & 4350 & 576 & 3068 & 3127 & 3179 & 806 & 725 & 415 & 415 & 1488 & 1424 \\
\hline As & $<0.156$ & $<2.19$ & $<0.461$ & $<1.85$ & n.d. & n.d. & n.d. & n.d. & n.d. & n.d. & $<0.454$ & $<1.23$ \\
\hline $\mathbf{R b}$ & $<0.010$ & $<0.062$ & $<0.031$ & $<0.113$ & $<0.013$ & $<0.014$ & $<0.017$ & $<0.015$ & 0.054 & 0.085 & 0.045 & 0.120 \\
\hline $\mathrm{Sr}$ & $<0.032$ & $<0.218$ & 0.131 & $<0.357$ & 0.02 & 0.02 & 1.16 & $<0.015$ & 0.39 & 0.92 & 0.545 & 1.334 \\
\hline $\mathbf{Y}$ & 0.260 & 0.060 & 0.907 & 7.809 & 0.012 & 0.014 & 1.72 & 0.189 & 8.709 & 2.053 & 0.060 & 0.037 \\
\hline $\mathrm{Zr}$ & 0.049 & $<0.084$ & 0.030 & 0.729 & 0.025 & $<0.01$ & 0.022 & 0.018 & 0.164 & 0.137 & 0.125 & 0.053 \\
\hline $\mathrm{Nb}$ & 0.003 & $<0.021$ & $<0.003$ & 0.032 & $<0.005$ & $<0.004$ & 0.011 & $<0.006$ & 0.015 & $<0.007$ & $<0.002$ & $<0.006$ \\
\hline Sn & $<0.0512$ & $<0.318$ & $<0.048$ & $<0.526$ & n.d. & n.d. & n.d. & n.d. & n.d. & n.d. & $<0.045$ & $<0.212$ \\
\hline Sb & 0.007 & $<0.033$ & $<0.008$ & $<0.040$ & n.d. & n.d. & n.d. & n.d. & n.d. & n.d. & $<0.009$ & $<0.016$ \\
\hline Cs & $<0.003$ & $<0.035$ & $<0.008$ & $<0.049$ & $<0.006$ & $<0.009$ & $<0.007$ & $<0.013$ & $<0.006$ & 0.01 & $<0.008$ & $<0.014$ \\
\hline $\mathrm{Ba}$ & 0.008 & $<0.044$ & 0.012 & $<0.039$ & 0.243 & $<0.018$ & 0.283 & 0.055 & 0.864 & 0.248 & 0.131 & 0.406 \\
\hline La & 0.004 & $<0.008$ & $<0.002$ & 0.016 & 0.006 & $<0.002$ & 0.133 & $<0.003$ & 0.041 & 0.032 & 0.018 & $<0.003$ \\
\hline $\mathrm{Ce}$ & 0.004 & $<0.006$ & 0.004 & 0.027 & 0.226 & $<0.001$ & 0.195 & $<0.003$ & 0.029 & 0.038 & 0.002 & 0.008 \\
\hline $\mathrm{Pr}$ & $<0.0007$ & $<0.003$ & $<0.0007$ & 0.014 & 0.003 & $<0.002$ & $<0.003$ & $<0.001$ & 0.014 & 0.01 & 0.005 & 0.001 \\
\hline Nd & 0.003 & 0.011 & 0.006 & 0.137 & $<0.017$ & $<0.008$ & $<0.013$ & $<0.013$ & 0.074 & 0.111 & 0.035 & $<0.007$ \\
\hline Sm & $<0.012$ & $<0.147$ & $<0.014$ & 0.126 & $<0.008$ & $<0.037$ & 0.015 & $<0.015$ & 0.152 & 0.03 & $<0.017$ & $<0.032$ \\
\hline $\mathrm{Eu}$ & $<0.001$ & 0.040 & 0.007 & 0.022 & $<0.003$ & $<0.003$ & 0.009 & 0.003 & 0.105 & 0.011 & 0.004 & $<0.005$ \\
\hline Gd & 0.005 & 0.005 & 0.015 & 0.124 & $<0.013$ & $<0.008$ & 0.05 & $<0.008$ & 0.684 & 0.116 & 0.001 & $<0.005$ \\
\hline Tb & 0.020 & $<0.022$ & 0.062 & 0.488 & $<0.001$ & $<0.001$ & 0.018 & $<0.002$ & 0.186 & 0.026 & 0.014 & $<0.012$ \\
\hline Dy & 0.035 & $<0.013$ & 0.122 & 1.028 & 0.007 & $<0.005$ & 0.2 & 0.023 & 1.307 & 0.282 & 0.007 & $<0.011$ \\
\hline Ho & 0.010 & $<0.003$ & 0.037 & 0.275 & $<0.003$ & $<0.002$ & 0.053 & 0.006 & 0.355 & 0.075 & 0.002 & 0.002 \\
\hline $\mathrm{Er}$ & 0.032 & $<0.014$ & 0.118 & 0.951 & $<0.008$ & 0.005 & 0.263 & 0.039 & 1.05 & 0.275 & 0.007 & $<0.011$ \\
\hline $\mathrm{Yb}$ & 0.045 & 0.069 & 0.162 & 0.932 & $<0.027$ & $<0.013$ & 0.453 & 0.099 & 1.059 & 0.388 & 0.006 & $<0.015$ \\
\hline Lu & 0.007 & 0.006 & 0.027 & 0.155 & 0.002 & 0.003 & 0.072 & 0.017 & 0.144 & 0.056 & 0.001 & $<0.003$ \\
\hline $\mathrm{Hf}$ & 0.005 & 0.019 & 0.005 & 0.062 & $<0.006$ & $<0.003$ & $<0.007$ & $<0.003$ & 0.052 & 0.008 & 0.003 & 0.006 \\
\hline $\mathrm{Ta}$ & 0.001 & $<0.013$ & $<0.005$ & $<0.019$ & $<0.003$ & $<0.001$ & $<0.001$ & $<0.003$ & 0.003 & 0.006 & $<0.003$ & $<0.005$ \\
\hline $\mathrm{Pb}$ & 0.007 & 0.063 & 0.003 & 0.045 & 0.055 & 0.028 & $<0.026$ & 0.039 & 0.732 & 0.158 & 0.019 & 0.071 \\
\hline Th & 0.002 & $<0.007$ & $<0.001$ & $<0.005$ & 0.006 & $<0.001$ & $<0.002$ & $<0.001$ & 0.004 & 0.005 & 0.001 & $<0.002$ \\
\hline U & 0.002 & 0.002 & $<0.0004$ & $<0.004$ & $<0.003$ & 0.002 & $<0.004$ & $<0.001$ & 0.003 & 0.002 & 0.001 & 0.003 \\
\hline
\end{tabular}




\begin{tabular}{|c|c|c|c|c|c|c|c|}
\hline \multirow{3}{*}{$\begin{array}{l}\text { matrix } \\
x x-3758\end{array}$} & \multicolumn{5}{|c|}{ Serpentinite sole } & & \\
\hline & \multicolumn{3}{|c|}{$\begin{array}{l}\text { Antigorite } \\
\text { Vein }\end{array}$} & \multicolumn{2}{|c|}{$\begin{array}{l}\text { Chrysotile } \\
\text { Vein }\end{array}$} & \multicolumn{2}{|c|}{$\begin{array}{c}\text { Polygonal } \\
\text { Vein and breccia matrix }\end{array}$} \\
\hline & KOP-3 & Ti-47 & $x x-3758$ & $x x-3786 a$ & $x x-3758$ & KOP-3 & xx3786a \\
\hline 0.170749 & $<0.069$ & $<0.209$ & 0.352 & $<0.048$ & 0.165 & $<0.173$ & $<0.072$ \\
\hline 5.12 & 7.00 & 8.07 & 4.85 & 3.01 & 4.65 & 7.20 & 6.28 \\
\hline 2.71 & $<1.81$ & 12.7 & 1.95 & $<1.64$ & $<1.60$ & $<4.56$ & 7.36 \\
\hline 84.5 & 206 & 289 & 119 & 168 & 158 & 139 & 267 \\
\hline 7.62289 & 22.8 & 85.2 & 19.9 & 9.59 & 14.3 & 48.1 & 33.2 \\
\hline 905 & 908 & 2146 & 938 & 471 & 526 & 2756 & 904 \\
\hline$<0.259$ & $<0.366$ & $<1.05$ & $<0.209$ & $<0.326$ & $<0.180$ & $<1.20$ & $<0.316$ \\
\hline 0.051 & 0.029 & 0.164 & 0.053 & 0.044 & 0.125 & 0.057 & 0.025 \\
\hline 1.454 & 0.416 & 2.245 & 2.847 & 0.384 & 2.306 & 0.556 & 0.308 \\
\hline 0.147 & 0.090 & 0.028 & 0.047 & 0.016 & 0.044 & 0.365 & 0.070 \\
\hline 0.025 & 0.077 & 0.076 & 0.045 & 0.054 & 0.017 & 0.205 & 0.120 \\
\hline$<0.002$ & $<0.002$ & $<0.015$ & $<0.001$ & $<0.001$ & $<0.001$ & $<0.009$ & $<0.003$ \\
\hline$<0.043$ & $<0.070$ & $<0.341$ & $<0.047$ & $<0.051$ & $<0.034$ & $<0.115$ & $<0.037$ \\
\hline$<0.005$ & 0.048 & $<0.028$ & 0.008 & 0.008 & $<0.005$ & 0.021 & 0.010 \\
\hline$<0.005$ & $<0.005$ & $<0.019$ & 0.012 & 0.007 & 0.018 & $<0.008$ & $<0.007$ \\
\hline 0.211 & 0.151 & 0.405 & 0.339 & 0.163 & 0.370 & 0.098 & 0.066 \\
\hline 0.058 & 0.043 & $<0.008$ & 0.020 & 0.005 & 0.014 & 0.110 & 0.017 \\
\hline 0.001 & 0.017 & $<0.010$ & 0.003 & 0.007 & 0.008 & $<0.007$ & 0.017 \\
\hline 0.014 & 0.014 & $<0.003$ & 0.004 & $<0.001$ & 0.004 & 0.049 & 0.008 \\
\hline 0.057 & 0.082 & $<0.018$ & 0.021 & 0.009 & 0.013 & 0.262 & 0.031 \\
\hline$<0.008$ & $<0.026$ & $<0.038$ & $<0.012$ & $<0.007$ & $<0.011$ & 0.058 & $<0.009$ \\
\hline 0.002 & 0.007 & $<0.011$ & $<0.002$ & $<0.002$ & $<0.001$ & 0.021 & $<0.003$ \\
\hline$<0.0007$ & 0.002 & $<0.002$ & 0.001 & $<0.0008$ & 0.001 & 0.008 & 0.001 \\
\hline 0.010 & 0.014 & $<0.025$ & $<0.005$ & $<0.005$ & 0.007 & 0.065 & 0.013 \\
\hline 0.010 & 0.011 & 0.012 & 0.005 & $<0.004$ & 0.006 & 0.024 & 0.007 \\
\hline 0.004 & 0.002 & $<0.002$ & 0.001 & $<0.0007$ & 0.001 & 0.009 & 0.002 \\
\hline 0.012 & 0.006 & $<0.007$ & 0.004 & 0.001 & 0.002 & 0.026 & 0.004 \\
\hline 0.011 & 0.006 & $<0.019$ & 0.004 & 0.004 & $<0.008$ & $<0.018$ & $<0.008$ \\
\hline$<0.001$ & $<0.001$ & $<0.003$ & 0.001 & $<0.0003$ & $<0.001$ & $<0.005$ & 0.002 \\
\hline$<0.004$ & $<0.005$ & 0.007 & 0.003 & 0.002 & 0.002 & $<0.010$ & $<0.003$ \\
\hline 0.004 & $<0.005$ & $<0.010$ & $<0.003$ & $<0.002$ & $<0.003$ & $<0.015$ & $<0.002$ \\
\hline 0.014 & 0.025 & 0.027 & 0.025 & 0.027 & 0.024 & 0.069 & 0.003 \\
\hline$<0.0003$ & $<0.0008$ & $<0.002$ & $<0.002$ & 0.001 & $<0.0008$ & $<0.002$ & $<0.0005$ \\
\hline 0.024 & 0.010 & $<0.003$ & 0.016 & 0.008 & 0.043 & 0.014 & 0.003 \\
\hline
\end{tabular}




\begin{tabular}{|c|c|c|c|c|c|c|}
\hline Sample & Location & Protolith & Position & Type & $\delta^{18} \mathbf{O}_{\text {SMOW }}$ & $\begin{array}{c}\mathbf{O D}_{\text {SMOW }} \\
\text { (0/) }\end{array}$ \\
\hline Por12-1 & Massif du sud & $\mathrm{Du}$ & US & liz & 2.2 & -106 \\
\hline Por12-2 & Massif du sud & $\mathrm{Du}$ & US & liz & 4.2 & -106 \\
\hline Por12-3 & Massif du sud & $\mathrm{Du}$ & US & liz & 2.9 & -106 \\
\hline Por6 & Massif du sud & $\mathrm{Hz}$ & US & WR & 5.3 & -66 \\
\hline Por11 & Massif du sud & $\mathrm{Hz}$ & US & WR & 5.5 & -75 \\
\hline Por12 & Massif du sud & $\mathrm{Du}$ & US & WR & 2.2 & -95 \\
\hline Kop6-1 & Kopéto & $\mathrm{Hz}$ & Sole & liz & 4.1 & -107 \\
\hline Kop6-2 & Kopéto & $\mathrm{Hz}$ & Sole & ant & 6.3 & -98 \\
\hline Kop6-3 & Kopéto & $\mathrm{Hz}$ & Sole & ant & 3.8 & -98 \\
\hline Kop6-4 & Kopéto & $\mathrm{Hz}$ & Sole & ant & 5.3 & -98 \\
\hline xx3758 & Koniambo & $\mathrm{Hz}$ & Sole & ant & 4.0 & -104 \\
\hline xx3773 & Koniambo & $\mathrm{Hz}$ & Sole & ant & 1.7 & -91 \\
\hline xx3778 & Koniambo & $\mathrm{Hz}$ & Sole & ant & 5.1 & - \\
\hline Ko-05-1 & Koniambo & $\mathrm{Hz}$ & Sole & chrys & 4.4 & -100 \\
\hline Ко-05-2 & Koniambo & $\mathrm{Hz}$ & Sole & chrys & 4.3 & -102 \\
\hline Ti 24-1 & Tiébaghi & $\operatorname{Lhz}$ & Sole & liz & 2.9 & -103 \\
\hline $\mathrm{Ti} 47-2$ & Tiébaghi & Lhz & Sole & liz & 5.7 & -97 \\
\hline Ti 48.06-1 & Tiébaghi & Lhz & US & liz & 5.4 & -97 \\
\hline Ti 48.06-2 & Tiébaghi & Lhz & US & liz & 5.6 & -103 \\
\hline Ti 5-1 & Tiébaghi & $\mathrm{Hz}$ & Sole & liz & 2.4 & -95 \\
\hline Ti 51c-1 & Tiébaghi & $\operatorname{Lhz}$ & Sole & liz & 3.0 & -104 \\
\hline Ti 47-3 & Tiébaghi & Lhz & Sole & ant & 1.9 & -88 \\
\hline Ti 47-3 dup & Tiébaghi & Lhz & Sole & ant & 2.1 & -88 \\
\hline Ti 52E & Tiébaghi & Lhz & Sole & ant & 4.9 & -95 \\
\hline Ti 52E dup & Tiébaghi & Lhz & Sole & ant & 5.3 & -95 \\
\hline Ti 5-3 & Tiébaghi & $\mathrm{Hz}$ & Sole & chrys & 1.7 & - \\
\hline Ti 51a-1 & Tiébaghi & $\operatorname{Lhz}$ & Sole & chrys & 9.5 & -91 \\
\hline Ti 51a-2 & Tiébaghi & Lhz & Sole & chrys & 10.8 & -91 \\
\hline Ti $54 b$ & Tiébaghi & Lhz & Sole & chrys & 4.9 & -94 \\
\hline Ti 51c & Tiébaghi & Lhz & Sole & WR & 2.6 & -88 \\
\hline Ti 24 & Tiébaghi & Lhz & Sole & WR & 1.9 & -90 \\
\hline Ti 47 & Tiébaghi & Lhz & Sole & WR & 5.8 & -87 \\
\hline Ti 48.06 & Tiébaghi & Lhz & US & WR & 6.4 & -97 \\
\hline Poum 17-1 & Poum & $\operatorname{Lhz}$ & US & liz & 6.8 & -103 \\
\hline $\begin{array}{l}\text { Poum 17-1 } \\
\text { dup }\end{array}$ & Poum & Lhz & US & liz & 6.9 & -103 \\
\hline Poum 18-1 & Poum & Lhz & US & liz & 6.5 & -101 \\
\hline Poum 4-5 & Poum & $\mathrm{Hz}$ & Sole & liz & 7.6 & -100 \\
\hline Poum 4-6 & Poum & $\mathrm{Hz}$ & Sole & liz & 13.9 & -94 \\
\hline Poum 4-1 & Poum & $\mathrm{Hz}$ & Sole & ant & 7.9 & -101 \\
\hline Poum 4-2 & Poum & $\mathrm{Hz}$ & Sole & ant & 12.2 & -104 \\
\hline
\end{tabular}




\begin{tabular}{|c|c|c|c|}
\hline Poum 4-3 & Sole & 12.1 & -104 \\
\hline $\begin{array}{c}\text { UWG-L gnt }(\mathrm{n}=10 ; \text {, valeur theorrque: } 5.8 \\
\% \mathrm{n})\end{array}$ & & $5.78 \pm 0.25$ & 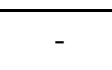 \\
\hline G1 Biotite ( $n=16$; valeur théorique: $-66 \%$ ) & & - & $-67 \pm 2$ \\
\hline
\end{tabular}




\begin{tabular}{|c|c|c|c|c|c|c|c|}
\hline Element & $\mathbf{B}$ & Th & $\mathbf{U}$ & $\mathbf{Z r}$ & U/Th & $\mathbf{B} / \mathbf{Z r}$ & References \\
\hline NC mantle wedge & 0.06 & 0.001 & 0.0005 & 0.053 & 0.5 & 1.13 & $\begin{array}{l}\text { U, Th, Zr: Secchiari et al. (2016; 2019); B: Salters and Stracke } \\
\text { ann }\end{array}$ \\
\hline AOC & 5.2 & 0.070 & 0.300 & 66.5 & 4.29 & 0.078 & U, Th, Zr: Staudigel et al; (1996); B: Smith et al. (1995) \\
\hline Mobility (\%) & 60 & 37.7 & 29.1 & 0.1 & & & Kogiso (1998); Sano et al. (2001) \\
\hline AOC-derived fluid $(F=1.5 \%)$ & 208 & 1.76 & 5.82 & 4.43 & 3.31 & 46.9 & Weight fraction of fluid F: Peacock (1990); Rüpke et al. (2004) \\
\hline GLOSS II & 67.9 & 8.10 & 1.73 & 129 & 0.214 & 0.526 & Plank (2014) \\
\hline Mobility (\%) & 70 & 2.5 & 3.0 & 0.1 & & & Aizawa et al. (1999) \\
\hline Sed-derived fluid $(F=3 \%)$ & 1584 & 6.75 & 1.73 & 4.3 & 0.256 & 368 & Weight fraction of fluid F: Peacock (1990); Rüpke et al. (2004) \\
\hline Abyssal serpentines & 50 & 0.073 & 0.569 & 2.4 & 7.79 & 20.8 & Peters et al. (2017) \\
\hline Mobility (\%) & 39.2 & 2 & 10 & 0.1 & & & Tenthorey and Hermann (2004) \\
\hline Serp-derived fluid $(F=0.69 \%)$ & 2841 & 0.212 & 8.25 & 0.348 & 39.0 & 8167 & Weight fraction of fluid F: Water loss during Lz/Ctl to Atg \\
\hline
\end{tabular}


Dear Pr Othmar Müntener,

Please find attached the corrected version of the manuscript written by by myself, Manuel Muñoz, Philippe Boulvais, Michel Cathelineau, Stéphane Guillot and Christian Picard entitled "Serpentinization of New Caledonia peridotites: from depth to (sub-)surface" that we submitted for publication to Contributions to Mineralogy and Petrology.

Following the very helpful comments made by yourself and the two reviewers, we made some substantial changes in the manuscript. They are listed below:

Dear Marc,

I have now received two reviews of your paper. Both reviewers are generally supportive of publication of your paper, but there are numerous issues to be resolved. The recommendation is between moderate to major revisions. I have also read your paper and agree mostly with their evaluations. Both reviewers provided many detailed comments for improving the overall presentation. Please follow their advice. There are, however, several major points that need careful attention. In brief you present a nice dataset, but you have not fully exploited its potential, which is reflected in a relatively general narrative, which lacks rigor of process discussion. This needs improvement along the following lines

(i) The paper needs generally a better organisation, more clearly defined research questions, a thorough discussion and then conclusions that take into account this discussion. Looking at the introduction, you invoke large scale processes (non-specific, see problems how you cite below), but in the discussion and conclusions these aspects have not been re-visited. This is too bad, because a reader will not get what are the novel things that one can learn from your study. You need to exploit the data in a more thorough way in order to make your study interesting for the reader.

(ii) The introduction on line 78 is poorly formulated, questions about the origin and nature of serpentinizing fluids can mean virtually everything. Please rewrite and be more specific what kind of research question do you want to address with your contribution and then discuss these in terms of the relevant processes. Otherwise a reader will get the impression of a local study. The general relevance of your findings should then be thoroughly discussed.

Answer to comments (i) and (ii): We agree with these comments. The introduction has been rewritten accordingly, and we tried to be more specific on the questions we addressed in this study. The large scale processes we invoked in the introduction are now re-visited in the discussion and the conclusions (see also our detailed answers to reviewers comments below).

(iii) Problems of correctly citing papers, somehow related to point (ii) above. I do not think that listing many many references is necessary. A few key references in the right place are in order. In particular you should cite the original and most important work of Ulmer and Trommsdorff (Science 1995, and Geochemical Society 1999) The works cited on line 70 and 71 refer all to these experimental studies but have not added new insights to this. When you talk about the importance of serpentine then a few papers that address the rheology of serpentine should be incorporated, not only geochemical literature. So focus on a few key references in the right place and do not provide long lists. Be specific when you add citations. 
An effort has been done in correctly citing papers. Original and most important works have been cited (e.g., Ulmer and Trommsdorff papers). A paragraph dealing specifically with the serpentine rheology and its role on rock exhumation has been added to the introduction (lines 79-84).

(iv) Some of the modelling needs serious rethinking and rewriting as outlined by reviewer \#1, and the methods how you have done the calculations needs to be better described and thoroughly discussed

The modeling has been rewritten and is now described in details (see answer to reviewer \#1).

(v) The discussion of the trace elements and its relationship with the stable isotopes needs to be expanded. As is, this is insufficient. On the one hand you use $A s, S b$ and call these sedimentary traces that are low, but $S r$ and $S r$ isotopes are high, derived from sediments. What is the importance of $U$ spikes in panel b,c,d and the Th/U ratio ? How important is the high Fe3+ in sole serpentinites? What is the Ce anomaly telling you? You need to milk these data more thoroughly, and then decide what you can say and what you cannot say. Mobility of incompatible elements depends on many parameters (Eh, $\mathrm{pH}$ of fluids) but you associate some anomalies to laterite formation, fair enough. But forming the sole in response to meteoric fluid circulation is not evident and the role of deformation on the trace element composition might be important. Retrogression of antigorite to chrysotile and polygonal serpentine is not isochemical, so what are the changes that you observe?

A new paragraph dealing with the behavior of trace elements has been added to the discussion, with 2 additional figures (lines 375-392). In addition, we have developed a new modeling that predict the evolution of the mantle wedge budget in trace element during slab dehydration. The results are compared with those of Monte Carlo simulations made on stable isotopes. The origin of $U$ spikes (high $U / T h$ ratios), low Ce/Ce* (i.e., Ce negative anomaly) and high $\mathrm{Fe}^{3+}$ in serpentine from the serpentinite sole have been extensively discussed (lines 612-622).

(vi) The final version needs to be read very carefully by a native English speaker. There are numerous franglisms in the paper, which need to be eliminated.

Done

From an editorial point of view, you need to complete the Table in the Electronic Appendix by providing GPS coordinates of all samples. So far I have not found any information where exactly the samples are collected.

Tables: It is not appropriate to report values in Tables that are 0.00 or 0.01 with std dev of 0.02 . Please replace these by the detection limit of your analysis. (e.g. TiO2 < 0.01). Relevant digits should be given only, e.g. SiO2 41.0 and not 41.04. Bdl in Table 2 should be replaced by the calculated limit of detection (e.g. Li < 0.3 ppm). Figures: please add relevant error bars in the figures. Not on all samples, but representative ones. Figure 5: I do not understand why you plot Fe3+/Fetot up to values of 1.1. The range is limited between 0 and 1 , the same is true for Mg\#, the grey field cannot exceed 1. So the axis should be limited to 1.

Figures: In general needs labels for indivual panels and these need proper description in the figure caption (see reviewer \#2 for improvement). Fig. 8 needs improvement (see reviewer\#1)

All your editorial suggestions have been taken into account and corrected accordingly. In most diagrams, the error bars are not reported because they are smaller than the size of the points.

Note that Contributions to Mineralogy and Petrology has no title numbering and you should consult the webpage for correct formatting of the manuscript, figures, figure captions and tables. 


\section{Reviewer 1}

Overall the paper presents interesting work that provides insights into the serpentinization process of the Peridotite Nappe of New Caledonia. The integration of mineralogical, major and trace element geochemistry, and particularly the isotope geochemistry and Monte Carlo and AOC fluid composition modeling is a creative way to develop an interpretation of the serpentinization process. However, there is a general lack of detailed description of the methods and some of the figures need substantial modification to be most effective.

Considering these limitations, I cannot recommend publication until after substantial revision and potential rereview.

\section{Major comments:}

In the introduction, as justification for the work, the significance of the work in general, in regard to understanding plate tectonics and global geochemical cycles is stated. However, these ideas are not revisited in the discussion or conclusions of the manuscript. Thus, the broader significance of what has been learned from this work needs to be developed in more detail.

We agree with this comment, and the discussion has been revisited accordingly. In particular, we have added a paragraph dealing with and modelling the behavior of some trace elements during the dehydration of subducted slab components and subsequent hydration of the overlying mantle wedge. The behavior of trace elements during late serpentinization events has been discussed more thoroughly, and how serpentines participate to the global geochemical cycles is now better described (e.g., lines 520-574)

The methods section does not contain enough detailed information. Particularly the methods for the modeling of the delta180/deltaD are not addressed in the methods section of the paper and are mostly constrained to the caption of Figure 7. This is not adequate and the methods must be much more fully described within the main body text. Similarly, the method for determining Fe3/FeT is not stated in the method section and needs to be described and/or referenced.

We do not find appropriate to develop our modeling approach in the Materials and Methods section, particularly because the first paragraph of the Discussion deals with the main limitations of modeling approaches that were previously published in the literature and highlights the benefits of our original approach. However, we agree that the modeling methods have to be better and fully developed, which is now the case in the present version: a new paragraph has been added at the beginning of the Discussion where the modeling approach is fully developed, including the equations used to calculate fractionation factors, the main equation used to calculate the isotopic compositions of serpentine as a function of mantle and fluids compositions, fractionation factors and fluid-rock ratio, and the proper references (lines 424-478).

The method for determining $\mathrm{Fe}^{3+} / \mathrm{FeT}$ (Beard and Frost, International Geology Reviews, 2016) have been described in details in the Materials and Methods section (lines 174-190).

Figure 7. Modeling methods should be removed from caption/figure and stated more completely in a dedicated section in the manuscript text. It is not clear enough that there are a couple of different models, that to some degree iterate on one another, involved in determining the temperature of the serpentinizing fluids. There is no justification of using Alt and Shanks 2006 to model the AOC isotopic composition which was then used to narrow the results from the Monte Carlo simulations.

We agree with this comment and the figure caption has been modified accordingly. In addition, as stated above, the manuscript now includes a section developing the modeling approach. The use of Alt and Shanks III study 
(2006) is argued on the basis of the regional geodynamics in the Marianna, which is assumed to be relatively similar to that expected for the South Loyalty Basin at the subduction time. In addition, the Marianna region is the only one so far providing an "access" to fluid circulations in the forearc mantle via the occurrence of serpentinite seamounts. This is now clearly stated in the text (lines 494-519).

$7 b-$ It's not clear if the boundaries of the black box are significant. Please clarify. If they are, please somehow make it easier to interpret the values from the outline of the box.

Please list the isotopic values of fluid you are inferring on the plot, as these are the actual results and are difficult to read off of the plot as presented. Remove the AOC crustal mineralogy/composition info from Alt and Shanks, 2006, as this belongs in a better developed methods section in the text vs. only shown on the plot itself.

The AOC composition and mineralogy has been removed from the figure $7 \mathrm{~b}$, and details about the AOC modeling is now given in the text (lines 494-519). Basically, the black box symbolizes the range of $\mathrm{O}$ and $\mathrm{H}$ isotope compositions of fluids in equilibrium with metabasalts, assuming that the metasomatised basaltic basement has $\delta_{180}=8-11 \% 0$ and $\delta D=-90$ to $-120 \%$ (Alt, Gcubed, 2003), and a simple mineralogy of $48 \%$ albite, $48 \%$ chlorite and $2 \%$ calcite. The dehydration of metabasalts having these isotopic compositions and mineralogy would produce fluids with $\delta 180$ values of $2-8 \%$ o $\delta$ values of $-50 \%$ to $-90 \%$. Clearly, the boundaries of the black box are dependent of the chosen parameters. However, by keeping the AOC stable isotope composition as defined by Alt (2003), the variation of other parameters (i.e., the mineralogy and the temperature) would lead to increase or reduce the size of the box without significantly moving it. In the modified version of Figure 7 , the black box is now in dashed blue lines, and we add a supplementary purple box showing the fluids in equilibrium with the AOC at $200-400^{\circ} \mathrm{C}$, which illustrates that increasing the temperature leads to increase the $\delta 180$ range up to $\sim 10 \%$ without changing the range of $\delta \mathrm{D} . \mathrm{O}$ and $\mathrm{H}$ isotopic compositions of subducted serpentine and sediment-derived fluids as calculated by Alt and Shanks have been also added to the Figure.

The list of isotopic values of fluids inferred on the plot is now provided in a supplementary table. This table also includes T, fluid-rock ratios and isotopic compositions of serpentine for each simulation.

$7 c / 7 d$ - Please define directly what the cross-hatch pattern indicates. Please directly state why the cross-hatch pattern is constrained to the red area of the density plot of the Monte Carlo simulation results. Please indicate what proportion of total number of simulations is included in that hatched area vs. in the red AOC fluid window.

The white cross-hatched pattern in Figure $7 \mathrm{c} / 7 \mathrm{~d}$ corresponds to simulations that plot in the red area in $7 \mathrm{~b}$. It represents about $40 \%$ of $\sim 6500$ random simulations. This is now indicated in the main text and in the figure caption.

Figure 8 - Either more detailed labelling or indications of process (e.g. labeled arrows) need to be included on the figure itself and/or a more detailed description of the take home message of the figure needs to be included in the caption to make this figure useful. A description of how the rocks and processes from (A) are related to the rocks and processes in (B) would also make this figure more useful.

The Figure caption has been modified accordingly: It now includes a more detailed description of the take home message.

The paper needs to be thoroughly reviewed and corrected specifically for English grammar.

Done

\section{Line-by-line comments:}

Line 32 - 'admitted' is a strange word choice here 
Deleted

Line 34-35 - 'their possible association' what is this referring to? Please state directly.

Done

Line 59 - Is 'mantellic' actually a word?

Corrected

Line 67 - What is 'huge' and what are the implications on the geologic system of this water getting into the mantle? It is this that will make the process important.

The sentence has been modified as follow: "Thus, the uppermost part of the oceanic lithosphere is hydrothermally altered before entering subduction zones. Then, the dehydration of the subducting slab favors the formation of forearc serpentine, which hosts a large amount of water (up to 13 wt.\%). The circulation of such an amount of aqueous fluids may, in turn, transport fluid-mobile elements (FME) deep into the mantle down to $\sim 150 \mathrm{~km}$ (Ulmer and Trommsdorff 1995; Wunder et al. 2001). At temperature above $\sim 650^{\circ} \mathrm{C}$, serpentine is no longer stable and aqueous fluids are liberated by serpentine breakdown triggered mantle wedge melting that gives rise to arc volcanism (Hattori and Guillot 2003; Iwamori 1998; Reynard 2013; Schmidt and Poli 1998; Ulmer and Trommsdorff 1995; 1999)."

Line 113-114 - awkwardly worded in English.

The sentence has been rewritten.

Line 133 - what exactly does the term "upper serpentine" refer to? The whole package of serpentinitzed harz/ Iherz/dun? Please state this clearly.

Indeed the term "upper serpentine" refers to the whole package, this is now specified.

Section 3.1

No mention of a method for Fe3/FeT

No mention of the isotope model parameters, etc. in the methods section - they are only briefly touched on in the Discussion section and caption of Figure 7. More development of this is necessary.

The $\mathrm{Fe}^{3+} / \mathrm{Fe}_{\mathrm{T}}$ method is now fully developed (lines 174-190)

Line 232 - Clearly some Fe but how much compared to the Fe content of the primary olivine? E.g. how much Fe is in the serpentine?

Considering atom per formula unit calculations on the basis of 7 oxygens for both serpentine and olivine in order to compare, $\mathrm{Fe}=0.2$ in average in lizardite vs. $\mathrm{Fe}=0.32$ in average in olivine, which confirms the loss of Fe during serpentinization. This information is available in the supplementary table S1.

Line 253-255 - awkwardly worded.

Rephrased

Line 301-303 - Fe2/Fe3 estimated by eprobe analyses. A statement describing this method in more detail and its limitations should be included here or in the methods section. However, it does seem reasonable to use this method if the interpretations are limited and broad as they are in this work. 
Done (see the answer on Major comments above)

Line 332-334 - serpentines have a wide range of 180 while deltaD are homogeneous. Why? No systematic difference between serpentine varieties. Why? Upper serpentines (i.e. liz) have a narrow isotope composition while Lizardite in the serptinite sole have a wider range of isotopic compositions. Why the difference between the two?

We do not find it appropriate to discuss the reasons why serpentines exhibit chemical heterogeneities in the Results section. The origin of these heterogeneities is widely discussed and addressed in the Discussion section of the manuscript.

Line 390-392 - The authors state that they do not use the fractionation factors of Saccocia because they are limited to $T>250 \mathrm{C}$. Yet, as stated on lines 403-405, the fluids have been interpreted to have mainly been at 250-430C (which is >250)? Additionally, the fractionation factors from all the mentioned sources clo converge at $T$ of $x-x$. ask Eric for plot.

As it is now specified in the manuscript, the use of oxygen isotope fractionation factors from Saccocia et al. (2009) provides quite similar results to that of Wenner and Taylor (1971) in the temperature range of $250-450^{\circ} \mathrm{C}$. However the serpentine-water ${ }^{180} 0^{-160}$ fractionation factor of Wenner and Taylor (1971) is applicable at a wide range of temperature, contrarily to the experimental approach of Saccocia et al. (2009) of which fractionation factor was calibrated only for temperatures $>250^{\circ} \mathrm{C}$. As a consequence, the use of Wenner and Taylor fractionation factor was found more consistent in the aim of calculating the $\delta 180$ composition of serpentinizing fluids without any other constraints on serpentinization temperature. Who is Erik?

Line 404-406 - It isn't at all clear how the Monte Carlo simulations are used to get from the isotope space the values fall into (stated on line 403) to interpreting/knowing that the fluids interacted with the mantle at $T$ of 250-430C? This isn't clearly described anywhere in the manuscript and must be developed.

Following the reviewer's recommandations, how the Monte-Carlo simulations have been calculated is now fully developed (see the detailed answer in Major comments and the new section in the manuscript, lines 424-478)

Line 414-416 - The base is more serpentinized, correct? (At least, it is stated to be such on lines 108-109.) So, this isn't worded correctly because it's saying the serpentinization degree increases from bottom to top thus the bottom is less serpentinized and the top is more serpentinized. If this is not actually the case, there may be some confusion in terminology between the bottom/top of the ophiolite and the sole serpentintinites.

Corrected. Indeed, the serpentinization degree decreases from bottom to top...

Line 449-452 - If serpentinization of NC occurred prior to entering the subduction zone, is there a signature of this in the isotopes? It was stated earlier that the isotopes fall in the 'ophiolite serpentines' field vs. the oceanic serpentines field which seems to suggest that the processes that occurred in the subduction zone are not represented in the isotopic signature. Please clarify.

This paragraph has been clarified particularly due to the addition of a new model based on trace elements which confirms the results of the Monte-Carlo simulations, i.e., AOC-derived fluids are mainly responsible to the serpentinization of NC peridotites (see lines 520-574).

Figure 3. Why mention pyroxene in the caption if not shown in the figure?

Deleted 
3B. Is S1 cut by 3 successive generations of serp veins as stated or by 4 as indicated by the range that is stated (S2 to 55 which would be $52,53,54,55$ ).

S1 is crosscut by 4 serpentine veins, thanks. This is now corrected.

3d. It's not apparent that (d) clarifies anything, the labels on d should be put on b and still be understood. We do not agree with this comment. We would prefer to leave this figure without any annotations for a better appreciation of the readers.

Figure 5. This caption seems to include less observation/interpretation than captions for other figures and the reader would benefit if it included more observation/interpretation.

Figure 5 caption now includes more details.

Pg. 46 of the compiled pdf doesn't seem to belong in the manuscript.

It belongs to the Table 3 and the trouble is related to the automatic pdf conversion of the manuscript from the journal website.

\section{Reviewer 2}

\section{General comments}

This manuscript present details of serpentinization history of the New Caledonia ophiolite using petrological observations and a large geochemical dataset. The manuscript provides details on the formation of serpentinites in the ophiolite identifying multiple generation of serpentinization events based in petrography, geochemistry, stable isotopes and Monte Carlos simulations. They identify an early serpentinization event at high temperatures from AOC fluids during emplacement that is more developed towards the base of the ophiolite with $100 \%$ serpentinization and tapers upsection with lower degrees of serpentinization. Further serpentinization involved meteoric fluids result in the formation of chrysotile and polygonal serpentine with geochemical signatures similar to their precursors.

The manuscript would be suitable for publication in Contributions of Mineralogy and Petrology after moderate revisions.

Specific comments

Comments are arranged by section of the manuscript.

Geological settings

More details on the specific units described in the paper need a little description on this section. Describe the existence of the basal nappe and the upper serpentines. There is no clarity here on the existence of the serpentinite sole and the base of the peridotite nappe and its difference. This applies to Figure 1. If this is classification from the paper it should be more clearly stated in the results or in the discussion.

Following this comment, the existence of the basal serpentinite sole is clearly indicated in last paragraph of the introduction and the differences between the serpentinite sole and upper serpentines are now widely addressed in the different sections of the manuscript. Unfortunately, at Figure 1 scale, it is not possible to differentiate the serpentinite sole from the serpentinized peridotites in the ophiolitic massifs. 
Line 91 add reference for age of ophiolite. Line 102 Space missing after references

Done

Line 106-107 I suggest authors remove asbestos connection. Stating that the serpentinites have not been extensively studied is enough.

Done

Lines 106-124 I recommend that this paragraph is reorganized and rewritten to clarify. For readers not familiar with the New Caledonia ophiolite is really difficult to follow. For example in line 114 it is no clear to which group of co-workers is referring and how MAR samples are related to the New Caledonia serpentinites or the important of this combined dataset.

This paragraph has been reorganized and rewritten as suggested (lines 120-127)

Materials and methods

Line 131 If available it will be good to add sample coordinates either in Table 3 or in a supplementary table. Currently table 3 only list the massif for each sample. Considering that Massif du sud extends for tens of kilometers having precise locations would be useful.

Sample coordinates are now available in supplementary table 1.

Line 148 Minor suggestion remove thick.

Done

Line 148 It is not clear how they make take the average and how it relates to figure 4. Is the average for each point measured, for points in the same vein or each serpentine type?

It is for each point measured. This is now specified.

Line 160 Change french orthose to English orthoclase.

Done

Results

Line 206-209 This needs some reorganizing. It is confusing as written. If 10\% is rare it should be treated as such and state first that moving up section from the base peridotites have moderate to high degrees of serpentinization with some occurrences in the top massifs where it is limited $\sim 10 \%$.

The paragraph has been rephrased as suggested (lines 227-232).

Line 210-213 Again this needs some reorganization the paragraph jumps back and forward from the base of the ophiolite and the upper sections making hard to follow. I suggest each unit is described consecutively instead of jumping between them.

Done 
Line 214-216 This appears out of place. In the previous paragraph you mention the base and then come back to describe it here. Is this a new observation or was it previously describe by others? If the latter is true the difference between the base and the upper sections needs to be incorporated to the Geologic setting.

We do not fully agree with this comment. The serpentinite sole has never been extensively studied until recently by our group. In addition, this work is the first one identifying several serpentine generations in the serpentinite sole and providing a comprehensive dataset for each generation. Therefore, we would prefer to keep this paragraph at this place.

Lines 271 Try to be consistent on how numbers in this section are reported. For example, for Nio they report a range and for Mno they report average and confidence interval. This should be consistent across the manuscript. If reporting confidence interval include if it is one or two sigma. This should be done for all sections in the results.

We agree with this comment. Numbers are now given with a better consistency in all sections in the results.

Line 275 is there any variation in opx and olivine Mg\#? If so add variability. Line 276 Remove ) towards the end of the line.

There is no variation in opx and olivine Mg\# (now specified in the text)

Line 331 Correct typo on displays

Line 332 remove display or show.

Done

Line 334 It is not clear when they refer to varieties if it is the same as the generations. If they are the six generations described in the petrography section this needs to be more clearly stated.

The term varieties has been replaced by species in the manuscript. Species is used to distinguish e.g., lizardite from chrysotile, while generations is used to characterize the chronology of each serpentinization event.

Line 338 This sentence just repeat what was said in line 333 to 334 and can be removed. Please just confirm which is the correct range for d180 as it differs between the two sentences.

Not really the same but we agree that it was a bit confusing as it was written. The sentence has been rephrased to be clearer.

Lines 341-344 How much silica is present in the samples? Is it enough to truly shift the d180 and discard the heavy d180 samples? If silica had $d 180=30 \%$ to get to $d 180=13 \%$ in the mixture it will require $\sim 30 \%$ silica which should de identifiable prior to analysis. In figure 7 a they show that all discarded samples except one plot in the ophiolite serpentine field. This might not affect the results as their Montecarlo simulations have values up to $d 180=12 \%$.

The presence of silica was identified by XRD (not shown in the manuscript) but was not quantified. However, the predicted amount of $\sim 30 \%$ you made is consistent with our previous study on the carbonation and silicification processes of the serpentinite sole (Ulrich et al., CTMP, 2014), where we show on the basis of chemical mapping that discrete silicification may easily represent $30 \%$ of the rock without significantly modifying its texture. Although it is true that only one of our samples plot off of the ophiolite serpentine field, these 4 samples are really different from the others in terms of oxygen isotope composition. Thus we find more consistent to discard these samples which likely reflect a later, shallower process than serpentinization. 
Line 343 Global makes this sentence confusing. I recommend it to be removed.

Done

Discussion

Lines 374-377 talk about of the serpentine-magnetite geothermometer. The next sentence implies multiple approaches for estimating temperature however in this paragraph it only has one (serpentine-magnetite).

This paragraph has been coupled to the previous one in order to be more clear.

Line 381 add "fluids derived from....."

Done

Line 385-392 This section needs to be rewritten. It is confusing what fractionation factors were used for d180 and dD. In line 389 remove "quite". Line 391 it is not clear what authors mean with "is more consistent". If it is a preference based on experimental temperatures it should be said that.

This section has been deeply rewritten, and we now provide new details on how the Monte-Carlo simulations were calculated.

Line 392-393 I would add at the beginning of the sentence something like: Neither of this previous work describe......

This sentence has been deleted from the manuscript.

Line 419 Change "et" for "and"

Done

Line 438 Change "such materials" for sediments.

Done

Line 439 Change "with regards" for "compared"

Done

Line 439 Unreadable should be changed to unresolvable

Done

Line 473 Missing reference to support idea that sole was formed under more oxidizing conditions. This ties up with the following sentence that attribute high Fe3+ in polygonal serpentine to meteoric fluids and incorporating more than the precursors. This creates a conundrum as in Figure 5 the highest Fe3+ is for antigorite and lizardite that seems to be from S2-S4. This suggest that the late polygonal serpentine has less Fe3+ than the precursor lizardite/antigorite and needs to be clarified.

We agree with this comment. In the present version of the manuscript, $\mathrm{Fe}^{3+}$ is calculated using an alternative approach (Beard and Frost, 2017) which is clearly more consistent than the approach of Droop (1987) initially used. A direct consequence is that polygonal serpentine has now the highest $\mathrm{Fe}^{3+}$. The more appropriate 
reference that support the idea that sole was formed under oxidizing conditions is already cited (Muñoz et al., JGE, 2019).

\section{Figures}

Figure 3 Add sample numbers to panels or caption. For panel C the caption is not clear. When you mean same as $B$ is it the same thin section (insert) or same textures and serpentine generations in different sample?

The sample numbers have been added to the caption, and the caption for $\mathrm{C}$ panel has been corrected.

Figure 4 I suggest that in the top of the panel is S1 and goes down to S6 instead of the way is presented now.

Done

Figure 5 Add letters to panels. It would be good to add some transparency to the symbols. As presented is hard to match description in text with figure. For example line $299 \mathrm{Mg \#}$ in bastites range from 88 to 98 is impossible to see in figure.

Done

Figure 6 Add letters to panels or caption. Figure 7 Typo in AOC fluids in panels b,c,d

Done

We hope that you will now find this revised manuscript suitable for publication in Contributions to Petrology and Mineralogy. If you have any question, please, let me know at your convenience.

Sincerely yours,

Marc ULRICH 


\section{Click here to access/download \\ Electronic supplementary material Supplementary tables.xIsx}


Click here to access/download Electronic supplementary material Supplementary Figure.pdf 